Article

\title{
Revisiting the Role of Fiscal Policy, Financial Development, and Foreign Direct Investment in Reducing Environmental Pollution during Globalization Mode: Evidence from Linear and Nonlinear Panel Data Approaches
}

\author{
Mustafa Kamal $^{1}$ (D), Muhammad Usman ${ }^{2,3}{ }^{\mathbb{D}}$, Atif Jahanger ${ }^{4}$ (D) and Daniel Balsalobre-Lorente ${ }^{5,6, *(\mathbb{D})}$ \\ 1 Department of Basic Sciences, College of Science and Theoretical Studies, Saudi Electronic University, \\ Dammam 31454, Saudi Arabia; m.kamal@seu.edu.sa \\ 2 Institute for Region and Urban-Rural Development, Wuhan University, Wuhan 430072, China; \\ usman399jb@gmail.com \\ 3 Department of Economics, Government College University Faisalabad, Faisalabad 38000, Pakistan \\ 4 School of Economics, Hainan University, Haikou 570228, China; atif_jahanger@hotmail.com \\ 5 Department of Political Economy and Public Finance, Economics and Business Statistics and Economic Policy, \\ University of Castilla-La Mancha, 16002 Cuenca, Spain \\ 6 Department of Applied Economics, International Economy Institute University of Alicante, \\ 03690 San Vicente del Raspeig, Spain \\ * Correspondence: Daniel.Balsalobre@uclm.es
}

Citation: Kamal, M.; Usman, M.; Jahanger, A.; Balsalobre-Lorente, D. Revisiting the Role of Fiscal Policy, Financial Development, and Foreign Direct Investment in Reducing Environmental Pollution during Globalization Mode: Evidence from Linear and Nonlinear Panel Data Approaches. Energies 2021, 14, 6968. https://doi.org/10.3390/en14216968

Academic Editors: Magdalena Radulescu and Rafał Weron

Received: 15 September 2021 Accepted: 19 October 2021

Published: 23 October 2021

Publisher's Note: MDPI stays neutral with regard to jurisdictional claims in published maps and institutional affiliations.

Copyright: () 2021 by the authors. Licensee MDPI, Basel, Switzerland. This article is an open access article distributed under the terms and conditions of the Creative Commons Attribution (CC BY) license (https:// creativecommons.org/licenses/by/ $4.0 /)$.

\begin{abstract}
Fiscal policy is a crucial government tool for influencing and managing the national economy and creating a strong incentive for low carbon investment. Previous literature has reputable evidence that improving fiscal policy enhances environmental quality. However, the literature fails to classify the exact turning level (threshold point) below/above which the association may be negative or positive. In this regard, this research investigates the nexus between fiscal policy, foreign direct investment, financial development, trade openness, urban population, gross capital formation, labour force, and $\mathrm{CO}_{2}$ emissions in the era of globalization. The panel data set contained 105 countries over the period from 1990 to 2016. The empirical findings are estimated through linear and nonlinear panel data approaches such as fully modified ordinary least square and panel threshold regression. The subsequent findings are established: first, fiscal policy and globalization significantly increase environmental pollution. Second, the empirical results confirm the existence of the pollution haven hypothesis (PHV). Third, financial development and gross fixed capital formation are also considered some of the most crucial indicators to increase pollution levels. Fourth, trade openness, urban population, and labour force improve environmental quality. Fifth, panel threshold regression discovers that countries maintain a minimum level of fiscal policy at -1.2889 . Based on these empirical findings, this study suggests that policymakers and governments of these countries should take steps to restructure their industrial sector and design macroeconomic-level carbon-free policies to support the implementation of low-energy-intensive and lower carbon production technologies.
\end{abstract}

Keywords: $\mathrm{CO}_{2}$ emission; globalization; fiscal policy; pollution haven hypothesis; panel threshold model

\section{Introduction}

In recent decades, climate changes, global warming, and environmental pollution have garnered the concentration of researchers around the world by virtue of fast-growing industrialization, transportation, and population. Environmental degradation has a direct association with human health, and it also influences rainfall, wildlife, agriculture, and glacier melting [1]. In many countries, a large portion of net national income (NNI) is directly spent by the government, and its spending varies from $20 \%$ to $50 \%$ of GDP. Many governments revised and expanded fiscal spending policies to encourage the economy 
during the deep economic disasters that were initiated in 2008. Fiscal policies can aid the establishment of low carbon emissions and resilient environment development [2].

As Halkos and Paizanos [3] and López et al. [4] theoretically argued, the mechanisms of fiscal policy are declared as scale effect, composition effect, technique effect, and income effect: (1) Technical effect: increased fiscal spending on human capital (e.g., technical education, health), which results in the improvement of labour efficiency and lower $\mathrm{CO}_{2}$ emission. Furthermore, Sarkodie et al. [5] also argued that increasing human capital is helpful for the escalation of $\mathrm{CO}_{2}$ emissions and environmental degradation. (2) Composition effect means that human activities, caused by the accretion of human capital rather than physical capital, are more dangerous to the environment. (3) Income effect means that growing income makes it possible for residents to be concerned about environmental quality, with a demand for higher government spending. (4) Scale effect shows that higher economic growth may lead to an increase in $\mathrm{CO}_{2}$ emission pressures, which necessitates more fiscal spending to control the $\mathrm{CO}_{2}$ emissions.

Fiscal policy plays a risk-reducing role in open economics. Government spending and taxation are the two main tools of fiscal policy, which play a vital function not only in economic growth but also in a current account balance [6]. Related to that, a large number of studies investigate that fiscal spending is a significant tool of environmental pollution $[3,4,7,8]$. Although the development of environmental excellence is not the main objective, we used two proxies of fiscal policy: first, overall governmental spending $\%$ of GDP and, second, overall tax revenues \% of GDP to check the impact of fiscal policy on $\mathrm{CO}_{2}$ emissions.

Many economies try to enhance the level of economic growth and control environmental pollution; thus, globalization is playing a significant role in improving environmental quality through FDI transferred from the developed nations to less technologically advanced economies. Fiscal policy is hugely affected by globalization. It assists in determining capital and trade inflows. Developing economies require public investment in order to attract foreign direct investment and to obtain access to a worldwide market. The Corona virus (COVID-19) outbreak has interrupted international trade, government spending, and tourism, all of which have had an impact due to globalization [9]. In the last few years, cumulative globalization and its drawbacks have contributed to a world environmental disaster and brought about the recent COVID-19 as an expression of years of ecological destruction and human involvement in ecological systems [10]. Finance and trade openness are significant aspects in speeding up the development of the liberalization of economies. Due to the globalization process, liberalization is commonly known as a quick improvement or enhancement in inflows of information, skilful labour, and goods and services from one country to another country [11]. Foreign companies use advanced technologies and better management practices that are conducive to reducing $\mathrm{CO}_{2}$ emissions in host countries. The pollution haven hypothesis (PHV) states that there is a positive connection between foreign direct investment (FDI) and $\mathrm{CO}_{2}$ emissions [12]. Developed countries have more strict environmental regulations. To avoid the extra cost of holding to these rules and regulations, most companies of developed countries transfer their manufacturing to the developing economies with minimum onerous environmental limitations $[13,14]$. Figure 1 shows the typical inverted U-shaped association between FDI and $\mathrm{CO}_{2}$ emissions; both are reflecting pollution halo and haven hypotheses. Based on the above discussions, this research aims to examine the influence of globalization and fiscal policy on $\mathrm{CO}_{2}$ emissions in 105 countries from 1990 to 2016. The possible contributions of this research to the previous literature are fourfold: (1) According to the best of the authors' knowledge, this is the first research to discover the consequence of fiscal policy on $\mathrm{CO}_{2}$ emissions in the era of globalization. (2) The impact of foreign direct investment (FDI) on $\mathrm{CO}_{2}$ emissions is also examined; thus, the validity of the pollution haven hypothesis (PHV) or pollution halo hypothesis (PHL) is also evaluated. (3) This empirical study employs the full modified ordinary least square (FMOLS), dynamic ordinary least square (DOLS), and autoregressive distributed lag (ARDL) approaches in a linear way; however, for the estimation of nonlinear panel 
estimation, we applied panel threshold regression (PTR) for the observed countries, which has not been carried out before. (4) Another contribution is that the previous literature fails to classify the exact level (threshold point); this is the first research to investigate the threshold level among fiscal policy and $\mathrm{CO}_{2}$ emissions in the era of globalization.

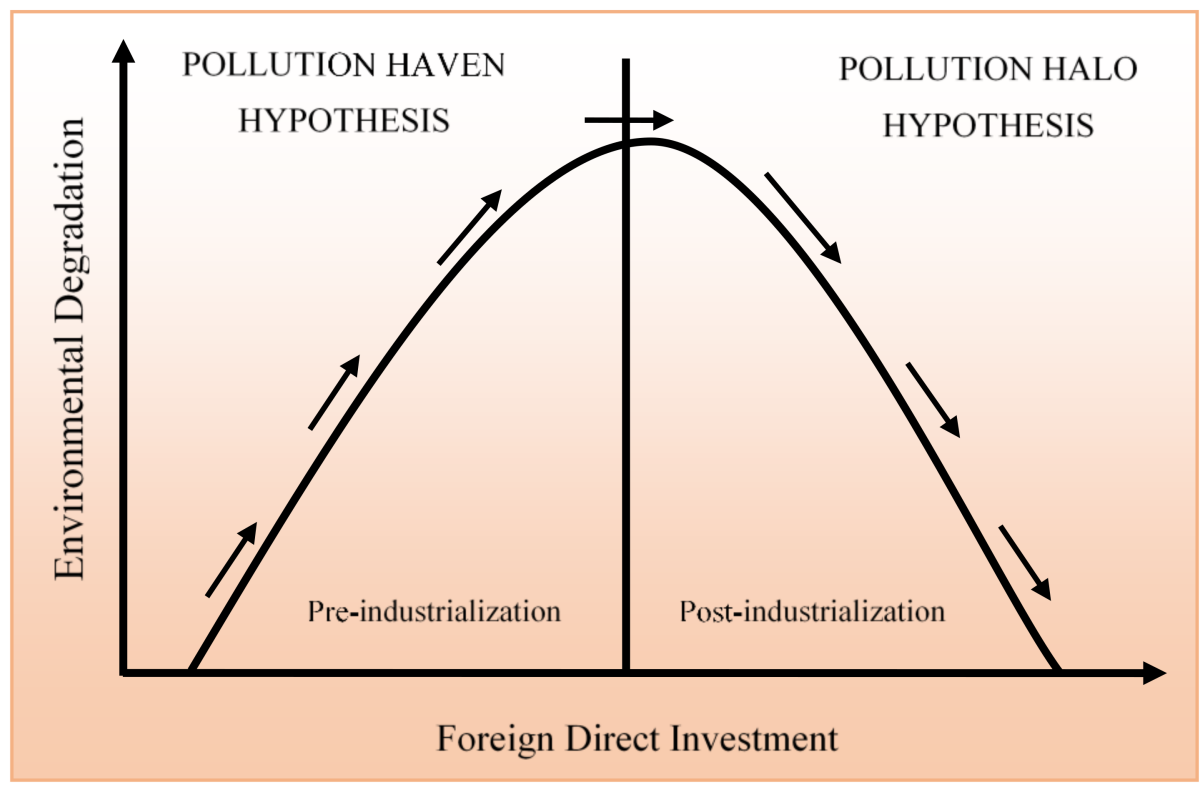

Figure 1. Inverted U-shaped link between FDI and environmental degradation.

The remaining portions of the study are ordered as follows: Section 2 summarizes the brief review of the literature regarding the nexus between fiscal policy, globalization, foreign direct investment, financial development, and $\mathrm{CO}_{2}$ emissions. Section 3 provides the data description, model specification, and methodological framework. Section 4 summarizes the empirical outcomes and discussions, and finally, Section 5 provides the conclusion and practical policy implications.

\section{Literature Review}

The nexus between fiscal policy, financial development, foreign direct investment, globalization, and $\mathrm{CO}_{2}$ emissions has been documented in various empirical studies. However, the literature has been divided into pairwise relations based on previous empirical findings between the variables that have been pointed out in the below given paragraphs.

\subsection{Nexus between Fiscal Policy and $\mathrm{CO}_{2}$ Emissions}

First, we review the existing literature that analyses the influence of fiscal policy on environmental degradation indicators. Among these studies, Ike et al. [15] examined the impact of fiscal policy, energy utilization, income, and environmental degradation using multiple structural breaks cointegration tests in the context of Thailand's economy. The findings suggest that there is a unidirectional causality from fiscal policy to environmental degradation and energy utilization. Similarly, Chishti et al. [16] investigated the relationship between fiscal policy, renewable energy consumption, and $\mathrm{CO}_{2}$ emissions in BRICS countries from 1985 to 2014 . The findings showed that fiscal policy enhances environmental quality by decreasing $\mathrm{CO}_{2}$ emissions. Furthermore, Ullah et al. [17] used the NARDL approach to research the relationship between fiscal policy and environmental degradation in Pakistan. The results indicate that fiscal policy improves environmental performance in the short term, while it enhances environmental degradation in the long run. Furthermore, Chan [18] employed the environmental dynamic stochastic general equilibrium (E-DSGE) approach by examining fiscal policy on environmental degradation. Their conclusion indicates that fiscal policy can stabilize environmental degradation and enhance household 
welfare. Jain et al. [19] investigate the influence of fiscal policy on environmental degradation based on ARDL and the panel data of nine Asian countries. The empirical outcomes indicate that fiscal policy has an asymmetric influence on environmental degradation because a positive change in expenditure minimized $\mathrm{CO}_{2}$ emissions, while a negative change in expenditure enhanced environmental degradation in the long run. Based on the panel data from the seven organizations for economic co-operation and development (OECD) countries from 1990 to 2018, and using the cointegration approach, Khan et al. [20] find an indirect influence of fiscal policy on environmental degradation through human capital and institutional quality. Furthermore, one-way causality runs from fiscal policy to $\mathrm{CO}_{2}$ emissions. In recent decades, the effect of fiscal policies on ecological contamination has become one of the interesting and debatable topics of interest for researchers. On this subject, Cheng et al. [21] study the relationship between fiscal policy and environmental degradation using the dynamic panel regression approach and the data of China's economy for the period from 1997 to 2015. An inverted U-shaped relationship exists between fiscal policy and environmental degradation. Furthermore, Langarita et al. [22] found that fiscal policy can be a potential instrument to boost renewables. Tufail et al. [23] indicated that fiscal policy and natural resources enhance environmental degradation by minimizing $\mathrm{CO}_{2}$ emissions.

\subsection{Nexus between Financial Development and $\mathrm{CO}_{2}$ Emissions}

Financial stability is crucial for economic and environmental stability, and for the same reason, a well-organized, sound, and developed financial sector promotes economic growth and protects environmental quality in the long run. Moreover, the positive role of developed financial structure in increasing economic progression has the ability to enhance energy utilization and in tandem has unplanned ecological distresses. In this pursuit, Lv and $\mathrm{Li}$ [24] investigate the association between financial development and environmental degradation in 97 global countries with spatial econometric techniques, and their findings indicate that financial development plays a significant role in the mitigation of environmental pollution. Shen et al. [25] consider financial development as one of the significant factors that enhance environmental degradation in the case of China. Furthermore, energy utilization and natural resources are also harmful to the environment. By using the dynamic seemingly unrelated regression (DSUR) technique, Yang et al. [26] research the long-run dynamic association of financial development and environmental degradation based on the panel data of Brazil, India, China, and South Africa (BICS) from 1990 to 2016; their outcomes reveal that financial development significantly deteriorates environmental performance. Usman et al. [27] examined the dynamic relationship of financial development and ecological footprint with the augmented mean group (AMG) approach and panel data of the top 15 highest emitting economies from 1990 to 2017. The empirical results indicate that financial development and renewable energy consumption help to minimize environmental degradation. Usman et al. [28] investigated the link between financial developments, tourism, renewable energy consumption, and environmental degradation in 52 economies from 1995 to 2017, and the empirical outcomes indicate that financial development significantly enhances environmental performance in the case of developed countries. Al-Mulali et al. [29], Shahbaz et al. [30], Bekhet et al. [31], and Cetin et al. [32] have found a positive and significant relationship between financial development and environmental degradation, while Zafar et al. [33], Dogan and Seker [34], Zaidi et al. [35], and Usman and Hammar [36] indicated that financial development negatively influences environmental degradation.

\subsection{Nexus between Foreign Direct Investment and $\mathrm{CO}_{2}$ Emissions}

The third important dynamic nexus of this subject literature is exploring the nexus between foreign direct investment and $\mathrm{CO}_{2}$ emissions. Nadeem et al. [37] examine the relationship between foreign direct investment inflow and $\mathrm{CO}_{2}$ emissions with autoregressive distributed lag (ARDL) and the time series data of Pakistan from 1971 to 2014. The 
empirical results support the existence of the pollution haven hypothesis (PHV) in the case of Pakistan. Moreover, Yilanci et al. [38] investigated the association between foreign direct investment inflow and $\mathrm{CO}_{2}$ emissions in Brazil, India, China, and South Africa (BRICS) with the bootstrap autoregressive distributed lag with Fourier (F-ARDL) model and conclude that foreign direct investment inflow significantly increases $\mathrm{CO}_{2}$ emissions in the case of China and also support the validity of the pollution haven hypothesis (PHV), but others countries had mixed results. Moreover, Balsalobre-Lorente et al. [39] found the relationship between foreign direct investment inflow and $\mathrm{CO}_{2}$ emissions using the full modified least square (FMOLS) and dynamic ordinary square (DOLS) in Mexico, Indonesia, Nigeria, and Turkey (MINT) countries during the period spanning from 1990 to 2013, and the results validate the PHV hypothesis for MINT countries. Rana and Sharma [40] study the causality connection between foreign direct investment inflow and $\mathrm{CO}_{2}$ emissions based on a dynamic multivariate Toda-Yamamoto (TY) approach and time-series data of India from 1982 to 2013. The empirical result confirms the existence of the PHV in India. Khan et al. [41] investigate the influence of foreign direct investment inflow on $\mathrm{CO}_{2}$ emissions based on an augmented mean group (AMG) and the panel data of five Belt and Road Initiative (BRI) countries from 1990 to 2016. The empirical consequences point out that foreign direct investment significantly increases $\mathrm{CO}_{2}$ emissions and also supports the existence of the PHV across the regions.

\subsection{Nexus between Trade Openness, Labour Force, and $\mathrm{CO}_{2}$ Emissions}

The current literature spotlights the association between trade openness, labour force, and $\mathrm{CO} 2$ emissions for different economies. In this regard, Ali et al. [42] analysed the relationship between eco-innovation, international trade, energy utilization, and environmental degradation in the top ten emitting economies with the cross-sectional ARDL (CS-ARDL) approach and conclude that innovation, international trade, and energy utilization are significant elements in explaining consumption-based $\mathrm{CO}_{2}$ emissions. Similarly, based on the second-generation techniques and the data of eleven countries from 1990 to 2016, Nathaniel et al. [43] found that international trade and energy utilization only slightly impact $\mathrm{CO}_{2}$ emissions. Likewise, Usman and Jahanger [44] indicated that financial expansion and trade openness significantly deteriorate environmental performance in the long run. Rehman et al. [45] have found that globalization, trade, and energy utilization significantly increase environmental deprivation. Lasisi et al. [46] investigate the influence of income, labour force, international truism, and $\mathrm{CO}_{2}$ emissions based on a two-step generalized method of moment (GMM) model and the panel data of OECD countries from 1995 to 2016. The empirical results indicate that the labour force has a negative influence on the environment, while international truism increases $\mathrm{CO}_{2}$ emissions. Furthermore, Qi and $\mathrm{Xu}$ [47] studied the relationship between the labour force and carbon emissions through the gravity model and the time-series data of thirty provinces for the period of 2002 to 2007 and 2010. The result indicates that the labour force could decrease $\mathrm{CO}_{2}$ emissions in the long run.

\subsection{Nexus between Urban Population, Gross Capital Formation, and $\mathrm{CO}_{2}$ Emissions}

In this strand, those empirical studies have been discussed that emphasize the dynamic influence of urban population and gross capital formation on environmental degradation. In this view, various scholars discover the urban population, gross capital formation, and $\mathrm{CO}_{2}$ emissions nexus taking the data for different regions and countries. Many studies uphold their argument that the use of urban population and gross capital formation increases environmental degradation, and others explore that it reduces it by curbing the disastrous effects of $\mathrm{CO}_{2}$ emissions. For instance, Anwar et al. [48] explored the dynamic association of urban population, international trade, and environmental degradation with the fixed effect approach and panel data of Far East Countries from 1980 to 2017. The empirical results indicate that urban population and international trade significantly determine environmental degradation. Abbasi et al. [49] considered that energy utilization, urban 
population, and $\mathrm{CO}_{2}$ emissions significantly and positively influence economic growth in the case of Pakistan. Rahman and Ahmad [50] examined the relationship between gross capital formation and $\mathrm{CO}_{2}$ emissions using nonlinear auto-regressive distribution lag (NARDL) regression and the time series of Pakistan during the period spanning from 1980 to 2016. They conclude that gross capital formation is the main element that increases $\mathrm{CO}_{2}$ emissions. Bekhet et al. [51] investigated the dynamic relationship between economic growth, financial development, energy consumption, gross capital formation, and $\mathrm{CO}_{2}$ emissions based on an ARDL model and the time series of Malaysia from 1970 to 2013. They conclude that gross capital formation could increase $\mathrm{CO}_{2}$ emissions.

In the above-mentioned literature, it is evident that the influence of fiscal policies on carbon emissions changes with the passage of time. These effects may differ according to the symphony of environmental pollution indicators, government spending, a single country or groups of the country, and the method of analysis. Furthermore, the existing literature that investigates the nexus between fiscal policies and environmental pollution often spotlight data sets with small sample sizes that may generate the problem of micronumerasticity. Moreover, almost all the existing studies have neglected the nonlinear relationship between fiscal policy, financial development, foreign direct investment, trade openness, globalization process, labour force, gross capital formation, urban population, and carbon emissions. These studies also do not investigate both linear and nonlinear relationships in a single model framework for these countries. For all these reasons, there is a research gap in the literature and we aim to fill this gap.

\section{Empirical Strategy}

\subsection{Model and Data}

This empirical research examines the impact of fiscal policy, foreign direct investment, financial development, trade openness, urban population, labour force, and gross capital formulation on $\mathrm{CO}_{2}$ emissions in the era of globalization. This research uses the balanced panel data of 105 countries (see Appendix A, Table A1) to analyse the influence of these carbon emissions determinants from a global perspective from 1990 to 2016. The functional expression of fiscal policy with other regressors during the globalization mode can be described in Equation (1) as follows:

$$
\mathrm{CO}_{2, \mathrm{it}}=\mathrm{f}\left(\mathrm{FP}_{\mathrm{it}}, \mathrm{TGL}_{\mathrm{it}}, \mathrm{X}_{\mathrm{it}}, \mu_{\mathrm{it}}\right)
$$

where $\mathrm{CO}_{2, \mathrm{it}}$ is carbon emissions per capita, $\mathrm{FP}_{\mathrm{it}}$ is a fiscal policy, and $\mathrm{X}_{\mathrm{it}}$ shows the vector of control variables including foreign direct investment, financial development, trade openness, urban population, labour force, and gross capital formulation $[14,38,52,53]$. All variables are converted in a natural logarithm to attain reliable results by reducing the problem of heteroscedasticity, normality, and data sharpness [54]. The log-linear specification of the analysed model is explained in Equation (2) as follows:

$\operatorname{lnCO}_{2, \text { it }}=\beta_{0}+\beta_{1} \operatorname{lnFP} P_{\text {it }}+\beta_{2} \ln \operatorname{lGL}_{\text {it }}+\beta_{3} \operatorname{lnFDI}_{\text {it }}+\beta_{4} \operatorname{lnFD}_{\text {it }}+\beta_{5} \ln \operatorname{lRD}_{\text {it }}+\beta_{6} \operatorname{lnURP}_{\text {it }}+\beta_{7} \operatorname{lnLLF}_{\text {it }}+\beta_{8} \operatorname{lnGCF}$ it $+\mu_{\text {it }}$

where subscripts $i$ represent the cross-sections ( $i=1,2 \ldots .105), \mathrm{t}$ represents the time period (1990-2016), and $\mu_{\mathrm{it}}$ represents stochastic error terms. The intercept term is denoted by $\beta_{0}$, and $\beta_{1} \rightarrow \beta_{3}$ are the parameters to be anticipated. In addition, $\mathrm{CO}_{2}$ presents the carbon dioxide emissions per capita; FP is a fiscal policy that has been constructed through principal component analysis (PCA) with two different indicators: first is overall government spending (GSP) as a \% of GDP and second is overall tax revenues (TR) as a \% of GDP. The TGL shows the total globalization index; foreign FDI denotes foreign direct investment; FD illustrates financial development; URP represents urban population; TRD shows trade openness; LF presents labour force; GCF explores the gross capital formulation. All the data for the variables are attained from the World Development Indicators of World Bank [55] database, excluding the measure of the globalization index, which will be obtained from the KOF Swiss Economic Institute updated by Gygli et al. [56] 
and Dreher [57] and the overall tax government spending variable has been attained from the International Monetary Fund (IMF) [58]. A detailed description of these variables is presented in Table 1. Moreover, the findings of PCA are presented in Table 2. In addition, Figure 2 shows the graphical presentation of scree plot and score variables of government spending and tax revenue for these studied countries.

Table 1. Measurement units of variables, acronyms, and data sources.

\begin{tabular}{|c|c|c|c|}
\hline Variables & Acronyms & Measurement Units & Data Sources \\
\hline $\mathrm{CO}_{2}$ per capita & $\mathrm{CO}_{2}$ & $\mathrm{CO}_{2}$ emissions (metric tons per capita) & World Bank [55] \\
\hline Government spending & GSP & $\%$ of GDP & $\mathrm{IMF}[58]$ \\
\hline Tax revenue & TR & $\%$ of GDP & World Bank [55] \\
\hline Total globalization index & TGL & KOF index (0 to 100$)$ & Dreher [57] \\
\hline Foreign direct investment & FDI & Net inflow (BoP, current USD) & World Bank [55] \\
\hline Financial development & FD & Domestic credit provided by financial sector (\% of GDP) & World Bank [55] \\
\hline Trade & TRD & $\%$ of total GDP & World Bank [55] \\
\hline Urban population & URP & $\%$ of annual growth & World Bank [55] \\
\hline Gross capital formation & GLF & $\%$ of total GDP & World Bank [55] \\
\hline Labour force & LF & Total labour force of population & World Bank [55] \\
\hline
\end{tabular}

Note. IMF denotes International Monetary Fund.

Table 2. Principal component analysis.

\begin{tabular}{|c|c|c|c|c|c|}
\hline \multicolumn{6}{|c|}{ Panel 1: Eigenvalues: $($ Sum $=2$, Average $=1)$} \\
\hline Number & Value & Difference & Proportion & Cumulative Value & $\begin{array}{l}\text { Cumulative } \\
\text { Proportion }\end{array}$ \\
\hline 1 & 1.510786 & 1.021572 & 0.7554 & 1.510786 & 0.7554 \\
\hline 2 & 0.489214 & - & 0.2446 & 2.000000 & 1.0000 \\
\hline \multicolumn{6}{|c|}{ Panel 2: Eigenvectors (loadings): } \\
\hline Variable & \multicolumn{2}{|c|}{ PC 1} & \multicolumn{3}{|c|}{ PC 2} \\
\hline TR & \multicolumn{2}{|c|}{0.707107} & \multicolumn{3}{|c|}{-0.707107} \\
\hline GSP & \multicolumn{2}{|c|}{0.707107} & \multicolumn{3}{|c|}{0.707107} \\
\hline \multicolumn{6}{|c|}{ Panel 3: Ordinary correlations: } \\
\hline Variables & \multicolumn{2}{|c|}{ TR } & \multicolumn{3}{|c|}{ GSP } \\
\hline TR & \multicolumn{2}{|c|}{1.000000} & \multicolumn{3}{|c|}{0.810786} \\
\hline GSP & \multicolumn{2}{|c|}{0.810786} & \multicolumn{3}{|c|}{1.000000} \\
\hline
\end{tabular}

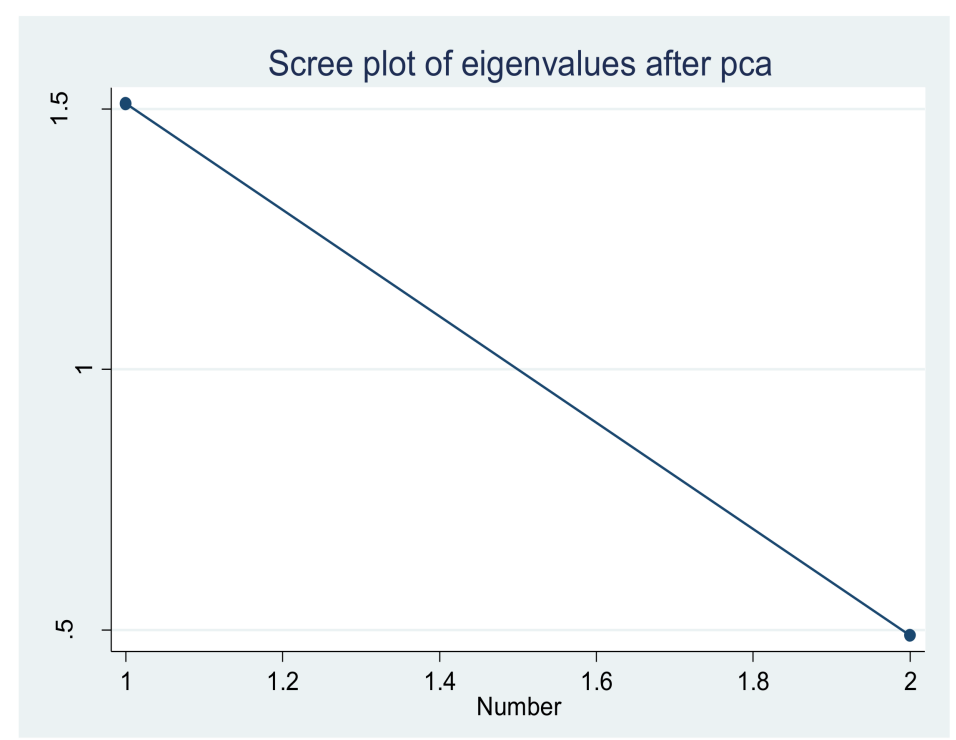

Figure 2. Cont. 


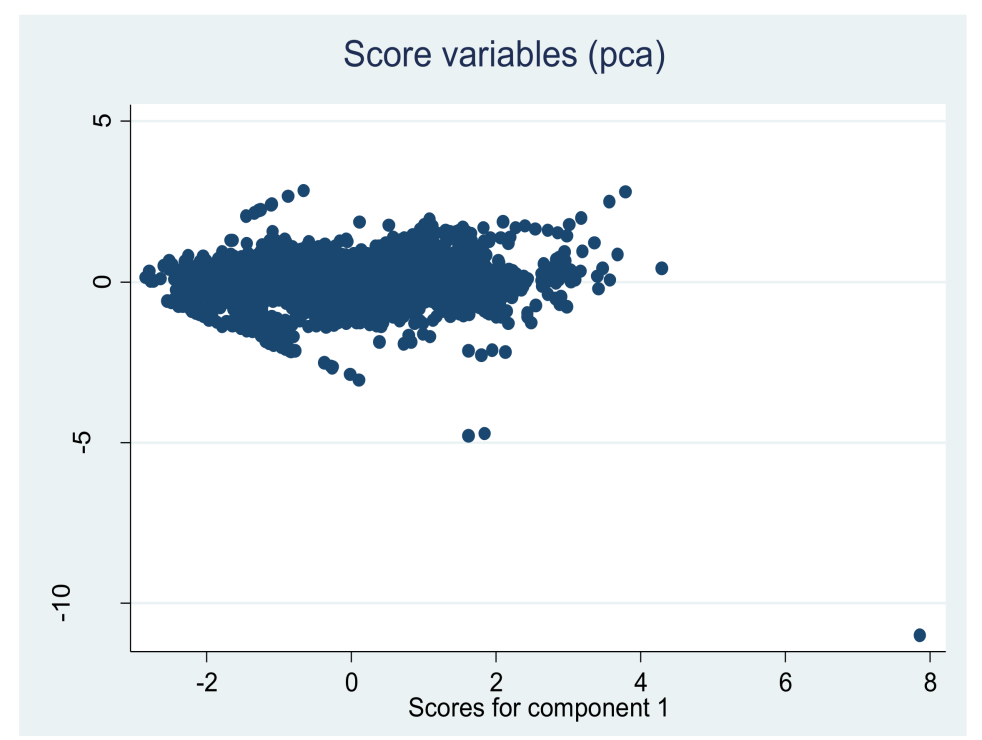

Figure 2. Scree plot and score variables of government spending and tax revenue.

\subsection{Panel Unit Root Tests}

In panel data analysis, a non stationary data series is the severe problem of spurious and biased regression, which additionally leads to errors in estimating the outcomes. In order to avoid this situation and investigate the stationarity order of the series, this study adopted four different panel unit root tests: Levin Lin and Chu (LLC), Im, Pesaran, and Shin (IPS), Fisher augmented Dickey-Fuller (F-ADF), and Fisher Phillips and Perron (F-PP) developed by Levin et al. [59], Im, Pesaran, and Shin (IPS) [60], Maddala and Wu [61], and Phillips and Perron [62], respectively. These tests are used to derive a panel-specific result. Hossain [63] applied the LLC stationary test in individual regression analysis, which is developed by Levin et al. [59] that can be expressed in Equation (3) as:

$$
\Delta \mathrm{Y}_{\mathrm{it}}=\alpha \mathrm{Y}_{\mathrm{it}-1}+\sum_{\mathrm{j}=1}^{\eta \mathrm{i}} \gamma_{\mathrm{ij}} \mathrm{Y}_{\mathrm{it}-\mathrm{j}}+\mathrm{x}_{\mathrm{it}}^{\prime} \varphi+\mu_{\mathrm{it}}
$$

where, under the assumption of $\alpha=\eta-1$, i.e., $\eta \mathrm{i}=\eta$ for all individual $\mathrm{i}$ but the difference term $\eta \mathrm{i}$ of the lag order is to cross-section variance and $\Delta \mathrm{Y}_{\mathrm{it}}=\mathrm{Y}_{\mathrm{it}}-\mathrm{Y}_{\mathrm{it}-1}$, where the null hypothesis $\left(\mathrm{H}_{0}\right)$ is expressed as $\mathrm{H}_{0}: \alpha=0$, and the alternative hypothesis is listed as $\mathrm{H}_{1}: \alpha<0$. The null hypothesis describes the variable containing the unit root problem, while the alternative hypothesis shows that there is the absence of a unit root problem in the series. This means that the variables contain the stationary process. In addition, the IPS panel unit root test is expressed in Equation (4) as:

$$
\begin{gathered}
\Delta \mathrm{y}_{\mathrm{it}}=\alpha_{\mathrm{i}} \mathrm{Y}_{\mathrm{it}-1}+\sum_{\mathrm{j}=1}^{\eta \mathrm{i}} \gamma_{\mathrm{ij}} \mathrm{Y}_{\mathrm{it}-\mathrm{j}}+\mathrm{x}^{\prime}{ }_{\mathrm{it}} \rho+\mu_{\mathrm{it}} \\
\overline{\mathrm{t}}_{\mathrm{nt}}=\frac{1}{\mathrm{n}} \sum_{\mathrm{i}=1}^{\mathrm{n}} \mathrm{t}_{\mathrm{iTi}}\left(n_{\mathrm{i}}\right)
\end{gathered}
$$


where the calculated ADF statistics are $t_{i T i}\left(\eta_{i}\right)$ for individual $i(i=1,2,3 \ldots \ldots \ldots \ldots N)$. In the second stage, by using the formula, the calculated standardized t-bar statistics can be estimated through Equation (6) as follows:

$$
\mathrm{Z}_{\mathrm{tnT}}=\frac{\sqrt{\mathrm{n}}\left[\overline{\mathrm{t}}_{\mathrm{nT}}-\frac{1}{\mathrm{n}} \sum_{\mathrm{i}=1}^{\mathrm{n}} \mathrm{E}\left(\overline{\mathrm{t}}_{\mathrm{iT}}\left(\eta_{\mathrm{i}}\right)\right)\right]}{\sqrt{\frac{1}{\mathrm{n}} \sum_{\mathrm{i}=1}^{\mathrm{n}} \operatorname{var}\left(\overline{\mathrm{t}}_{\mathrm{iT}}\left(\eta_{\mathrm{i}}\right)\right)}} \sim \mathrm{N}(0,1)
$$

where IPS provides for the different time periods of $t$ and $\eta$, the $\operatorname{var}\left(t_{i T}(\eta)\right)$ and $E\left(t_{i T}(\eta)\right)$ is followed. Additionally, this process indicates that in the presence of cross-sectional dependence data and t-bar, demeaned statistics can be adjusted and this process will lead to the standard normal distribution in the limit.

The Fisher-ADF and Fisher-PP panel unit root tests are specified in a detach ADF regression for every individual cross-section unit $i$, which can be estimated through Equation (7) as follows:

$$
\Delta y_{i, t}=\delta y_{i, t-1} \sum_{j=1}^{q_{i}} \beta_{i, j} \Delta Y_{i, t-j}+x_{i, t}^{\prime} \eta+\varepsilon_{i, t}
$$

The null hypothesis $\left(\mathrm{H}_{0}\right)$ of these tests can be articulated in Equation (8) as follows:

$$
\mathrm{H}_{0}: \delta_{\mathrm{i}}=0 \text { for } \forall \mathrm{i}
$$

Additionally, the alternative hypothesis $\left(\mathrm{H}_{1}\right)$ of these tests can be articulated in Equation (9) as follows:

$$
\mathrm{H}_{1}:\left\{\begin{array}{cc}
\delta_{\mathrm{i}}=0 & \text { for all } \mathrm{i}=1,2,3, \ldots \ldots \ldots \ldots \ldots \ldots, \mathrm{N}_{1} \\
\delta_{\mathrm{i}}<0 & \text { for all } \mathrm{i}=\mathrm{N}+1, \mathrm{~N}+2, \mathrm{~N}+3 \ldots \ldots \mathrm{N}
\end{array}\right.
$$

where the term i can be restructured as indispensably that can be described as a nonzero portion of the separate cross-sectional procedures.

\subsection{Panel Cointegration Tests}

The very next procedure of the empirical analysis is to test the long-run cointegration relationship among variables. To do this, we applied two different cointegration tests, namely, the Kao and Johansen cointegration tests developed by Kao [64] and Johansen [65], respectively. In this view, Kao [64] developed the residual-based long-run cointegration approach that relies on the panel adaptation of the augmented Dickey-Fuller (ADF) test statistics expressed in Equation (10) as follows:

$$
\mathrm{ADF}=\mathrm{t}_{\overline{\mathrm{p}}}+\sqrt{\frac{6 \mathrm{~N} \hat{\sigma}_{\mathrm{r}}}{2 \hat{\sigma}_{0 \mathrm{r}}}} / \sqrt{\frac{\hat{\sigma}_{0 \mathrm{r}}^{2}}{2 \hat{\sigma}_{\mathrm{r}}^{2}}}+3 \hat{\sigma}_{\mathrm{r}}^{2} \mathrm{r}_{\mathrm{r}}^{2} / 10\left(6 \hat{\sigma}_{0 \mathrm{r}}\right)
$$

However, the Johansen cointegration test allocates at least one co-integrating association and highlights all analysed series considered endogenous variables. Furthermore, Johansen's [65] method estimates a variety of long-run equilibrium relationships between incorporated time series, despite the implementation of the normalization procedure. Additionally, this cointegration test establishes whether two or more than two series are long-run cointegrated by using the standard co-integrating equation such as Equation (11):

$$
\mathrm{y}_{\mathrm{t}}=\mathrm{M}_{1} \mathrm{y}_{\mathrm{t}-1}+\mathrm{M}_{2} \mathrm{y}_{\mathrm{t}-2}+\mathrm{M}_{3} \mathrm{y}_{\mathrm{t}-3}+\ldots \ldots \ldots \ldots \ldots+\mathrm{M}_{\mathrm{p}} \mathrm{y}_{\mathrm{t}-\mathrm{p}}+\beta \mathrm{x}_{\mathrm{t}}+\mu_{\mathrm{t}}
$$


where trace statistics are used in the absence of cointegrating vectors conjecture, as followed by Equation (12):

$$
\text { Trace }=-\mathrm{T} \sum_{\mathrm{i}=\mathrm{r}+1}^{\mathrm{p}} \ln \left(1-\hat{\pi}_{\mathrm{i}}\right)
$$

Additionally, identifying the maximum eigenvalue in the existence of accurate cointegration vector that can be estimated through Equation (13) as follows:

$$
\pi_{\text {maximum }}=\operatorname{Tln}\left(1-\hat{\pi}_{\mathrm{i}}\right)
$$

\subsection{Long-Run Elasticity Estimates (Linear)}

\subsubsection{Full Modified Ordinary Least Square (FMOLS)}

Since the variables restrain the long-run cointegration linkages, the long-run coefficients of the analysed series must be anticipated in the next econometric procedures $[66,67]$. To do this, the fully modified ordinary least square (FMOLS) approach grasps the estimators interconnected to normally distributed and asymptotically unbiased, not including any impact of endogenous response, and additionally, it is well known as a nonparametric approach [28,68]. In addition, Monte Carlo simulation in a small sample (micronumerasticity issue) illustrates that if time periods are relatively shorter as compared to the individual cross-sections $(\mathrm{T}<\mathrm{N})$, the predictable coefficients in the course of the FMOLS estimator will not generate biased and inconsistent parameters. One more advantage of the FMOLS method is to address the endogeneity, heteroscedasticity, and serial correlation issues in the anticipated coefficients in the panel data sample [14,28]. The Pedroni-based [69] mathematical expression of the FMOLS estimation test is written in Equation (14) as follows:

$$
\hat{\beta}_{\mathrm{FMOLS}}^{*}=\mathrm{N}^{-1} \sum_{\mathrm{n}=1}^{\mathrm{N}} \hat{\beta}_{\mathrm{FMOLS}, \mathrm{n}}^{*}
$$

where $\hat{\beta}_{\mathrm{FMOLS}, \mathrm{n}}^{*}$ shows the estimators of the FMOLS approach for all individual crosssections. The FMOLS-based t-statistics can be estimated through Equation (15) as follows:

$$
\mathrm{t}_{\hat{\beta}_{\mathrm{FMOLS}}}=\mathrm{N}^{-1 / 2} \sum_{\mathrm{n}=1}^{\mathrm{N}} \mathrm{t}_{\beta_{\mathrm{FMOLS}, \mathrm{n}}}
$$

where $t_{\hat{\beta}_{\mathrm{FMOLS}}}$ indicates the t-statistic of the FMOLS estimator.

\subsubsection{Dynamic Ordinary Least Square (DOLS)}

Initially, McCoskey and Kao [70] developed the dynamic ordinary least square (DOLS) method, and later on, the DOLS approach was modified by Mark and Sul [71] for the panel data analysis. This estimation approach has the ability to estimate the parameters for the $\log -\log$ model. The key advantage of this method is that this method has more ability to tackle the problem of heteroscedasticity, endogeneity, and serial correlation due to its parametric estimator nature and the application of Monte Carlo simulations [14]. To estimate the econometric function, the DOLS approach can be estimated through Equation (16) as follows:

$$
\hat{\beta}_{\text {EFPDOLS }}^{*}=N^{-1} \sum_{n=1}^{N} \hat{\beta}_{\text {DOLS, } n}^{*}
$$

where the term $\hat{\beta}_{\text {DOLS, } n}^{*}$ ilustrates the DOLS estimator, which can be applied on all $\mathrm{n}$ cross-sections. However, the t-statistics test of this method is presented in Equation (17) as follows:

$$
\mathrm{t}_{\hat{\beta}_{\text {DOLS }, \mathrm{n}}^{*}}=\mathrm{N}^{-1 / 2} \sum_{\mathrm{n}=1}^{\mathrm{N}} \mathrm{t}_{\hat{\beta}_{\text {DOLS }, \mathrm{n}}^{*}}
$$




\subsubsection{Autoregressive Distributive Lag Model (PMG/ARDL)}

Pesaran et al. [72] and Pesaran and Smith [73] developed the pooled mean group (PMG) approach by approximating the longitudinal data method well known as the panel autoregressive distributed lag (ARDL) method. The ARDL approach should be applied to the carbon emissions function to discover the long-term and short-term dynamics. To estimate the long-run dynamics among the selected variables, we calculate the ARDL method through Equation (18) as follows:

$$
\begin{gathered}
\left.y_{i, t}=\sum_{j=1}^{p} \lambda_{i, j} y_{i, t-j}+\sum_{j=0}^{p} \pi_{i, j} x_{i, t-j}+\varepsilon_{i}+\varepsilon_{i, t}\right) \\
\varepsilon_{i, t}=\gamma_{i} d_{i, t}+\gamma_{i, t}
\end{gathered}
$$

where $\varepsilon_{i, t}$ shows the estimator of fixed effect, $\mathrm{x}_{\mathrm{i}, \mathrm{t}-\mathrm{j}}$ indicates the vector of explanatory variables (regressors) matrix, the vector of coefficient $(\mathrm{k} \times 1)$ is denoted by $\pi_{\mathrm{i}, j}$, and $\lambda_{i, j}$ shows the lagged variable parameter and indistinct ordinary trauma. In this way, Equation (18) can be reported in Equation (20) as follows:

$$
\Delta \mathrm{y}_{\mathrm{i}, \mathrm{t}}=\Psi \mathrm{y}_{\mathrm{i}, \mathrm{t}-1}+\theta \mathrm{x}_{\mathrm{i}, \mathrm{t}}+\sum_{\mathrm{j}=1}^{\mathrm{p}=1} \lambda_{\mathrm{i}, \mathrm{j}}^{*} \Delta \mathrm{y}_{\mathrm{i}, \mathrm{t}-\mathrm{j}} \sum_{\mathrm{j}=0}^{\mathrm{q}-1} \pi_{\mathrm{i}, \mathrm{j}}^{*} \Delta \mathrm{x}_{\mathrm{i}, \mathrm{t}-1}+\varepsilon_{\mathrm{i}}+\varepsilon_{\mathrm{i}, \mathrm{t}}
$$

where $\pi_{\mathrm{i}, \mathrm{j}}^{*}$ indicates the coefficients vector.

$$
\Psi_{i}=-\left(1-\sum_{j=1}^{p} \lambda_{i, j}\right) \text {, and } \theta_{i}=\left(\sum_{j=0}^{p} \pi_{i, j}\right)
$$

\subsection{Panel Threshold Regression (Nonlinear)}

The panel threshold model proposed by Hansen $[74,75]$ is a suitable solution that can identify the turning levels. We define our threshold regression with a single threshold value, recognized as follows:

$$
y_{i, t}=\left\{\begin{array}{l}
\mu_{i}+\alpha_{1} X_{i, t}+\beta_{1} q_{i, t}+\varepsilon_{i, t}, q_{i}<\gamma \\
\mu_{i}+\alpha_{2} X_{i, t}+\beta_{2} q_{i, t}+\varepsilon_{i, t}, q_{i} \geq \gamma
\end{array}\right.
$$

where $\mathrm{y}$ is the dependent $\left(\mathrm{CO}_{2}\right.$ emissions) variable, $\mathrm{X}$ is the vector of an independent variable, and $q$ is the threshold variable fiscal policy, $i$ and $t$ indicate the country and time, $\alpha_{1}, \alpha_{2}, \beta_{1}$, and $\beta_{2}$ are coefficients of independent variables, $\gamma$ is threshold variable, $\mu_{\mathrm{i}}$ is the fixed effects, $\varepsilon_{i, t}$ is the error term with unspecified finite variance, zero mean, and identical and independent distribution. After examining the single threshold, the additional threshold (double and triple) will be observed. For example, the following represents a second threshold:

$$
y_{i, t}=\left\{\begin{array}{c}
\mu_{i}+\alpha_{1} X_{i, t}+\beta_{1} q_{i, t}+\varepsilon_{i, t}, q_{i, t}<\gamma_{1} \\
\mu_{i}+\alpha_{2} X_{i, t}+\beta_{2} q_{i, t}+\varepsilon_{i, t}, \gamma \leq q_{i, t} \geq \gamma_{2} \\
\mu_{i}+\alpha_{3} X_{i, t}+\beta_{3} q_{i, t}+\varepsilon_{i, t}, q_{i, t} \geq \gamma_{3}
\end{array}\right.
$$

where $\alpha_{3}$ and $\beta_{3}$ indicate the coefficients of the independent series and the threshold variables. In addition, $\gamma_{1}, \gamma_{2}$, and $\gamma_{3}$ show the different threshold values.

\section{Results and Discussion}

The descriptive statistical analyses of the variables from the global sample of 105 countries are expressed in Table 3. This shows that all the candidate variables include $\mathrm{LCO}_{2}$, LFP, LTGL, LFDI, LFD, LFD, LTRD, and LGCF have a long-left tail and lowest negative skewness. However, foreign direct investment (20.5860) accompanied by labour force 
(15.4299) are the maximum/higher average values among the other variables. The lowest/minimum average value for urban population (0.42515) and $\mathrm{CO}_{2}$ emissions is (0.85362). Furthermore, Kurtosis outcomes are approximately 2-25 for almost all concerned variables, which recommended a sign of linearity among the variables. The summary statistics of concerned variables from 1990 to 2016 are demonstrated through box plots in Figure 3.

Table 3. Descriptive statistics.

\begin{tabular}{cccccccc}
\hline & Mean & Median & Maximum & Minimum & Std. Dev. & Skewness & Kurtosis \\
\hline LCO $_{2}$ & 0.85362 & 1.24676 & 3.58117 & -3.86743 & 1.51485 & -0.73682 & 2.89665 \\
LFP & 2.61183 & 15.2137 & 3.88287 & -3.13511 & 0.664202 & -0.2371 & 2.02769 \\
LTGL & 4.06436 & 4.11082 & 4.51429 & 2.96582 & 0.30552 & -0.79715 & 3.27120 \\
LFDI & 20.5860 & 20.7805 & 27.3217 & 2.30258 & 2.78277 & -0.83094 & 5.77482 \\
LFD & 3.79566 & 3.95761 & 10.8081 & -4.67196 & 1.18458 & -1.74790 & 12.2953 \\
LTRD & 4.24519 & 4.28122 & 6.08068 & -1.78726 & 0.65404 & -2.96416 & 25.2427 \\
LURP & 0.42515 & 0.66434 & 7.26566 & -8.60548 & 1.26919 & -1.70453 & 10.1602 \\
LLF & 15.4299 & 15.3630 & 20.4875 & 10.9671 & 1.64369 & 0.21535 & 3.29817 \\
LGCF & 3.14435 & 3.14769 & 4.21819 & 0.15455 & 0.33534 & -1.78584 & 13.9852 \\
\hline
\end{tabular}

Note. Std. Dev. denotes the standard deviation.

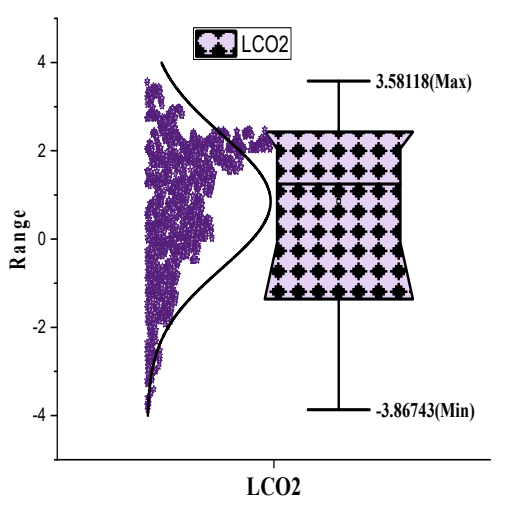

(a)

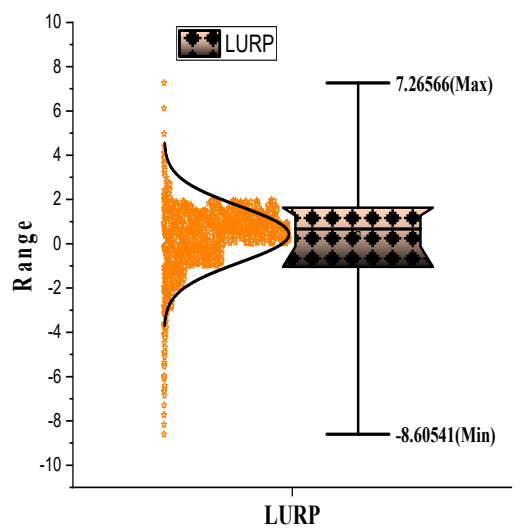

(d)

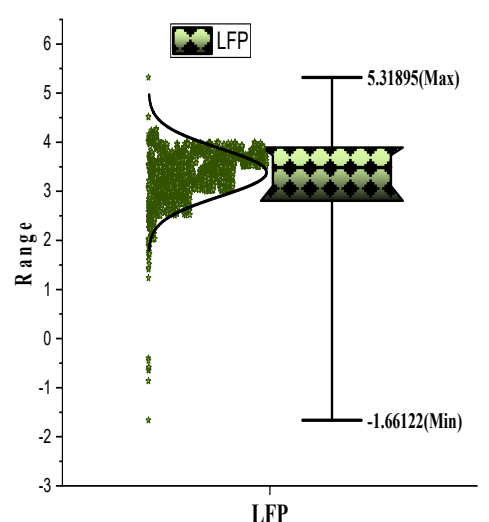

(b)

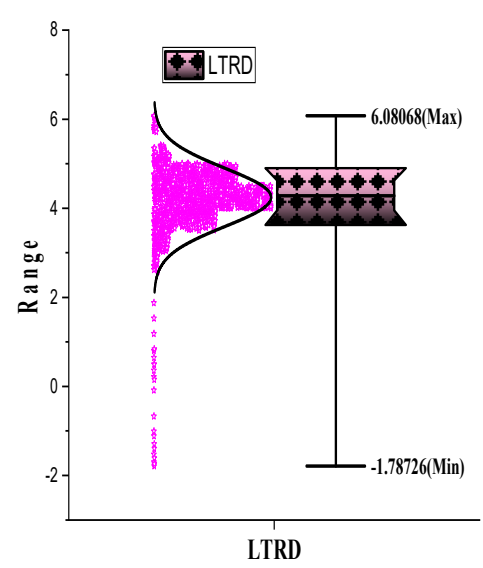

(e)

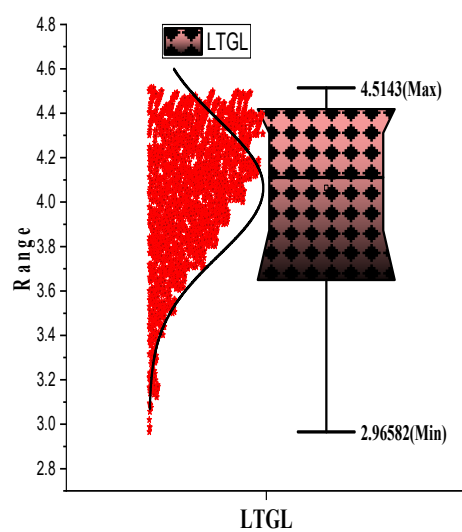

(c)

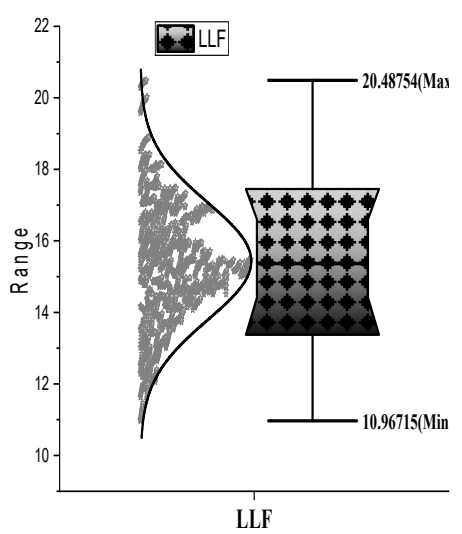

(f)

Figure 3. Cont. 


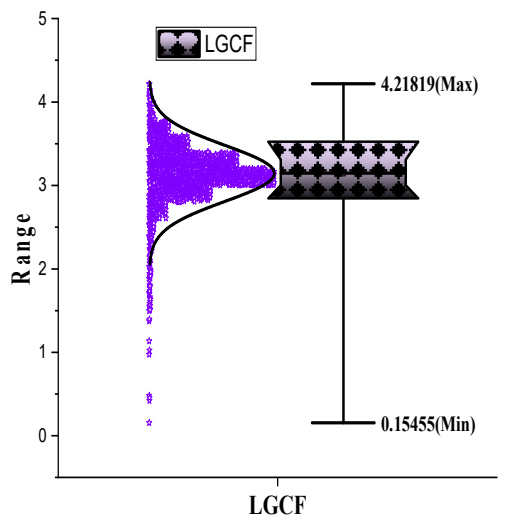

(g)

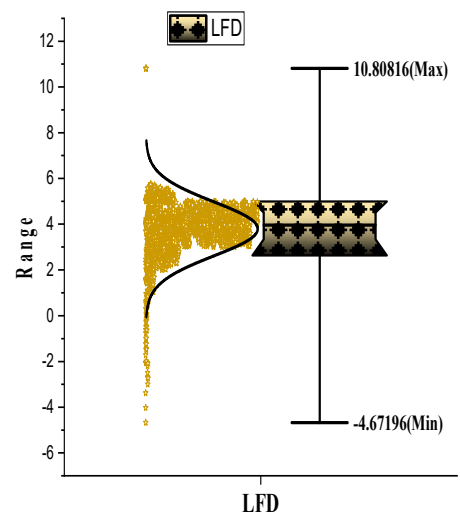

(h)

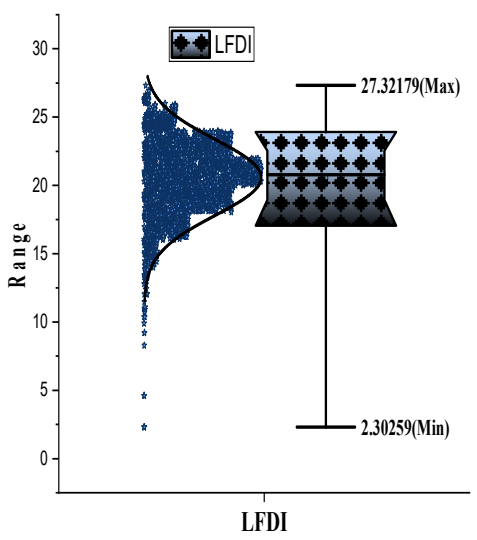

(i)

Figure 3. Box-plot statistics of the concerned variables such as (a) LCO2; (b) LFP; (c) LTGL; (d) LURP; (e) LTRD; (f) LLF; (g) LGCF; (h) LFD, and (i) LFDI.

Following the natural logarithm of analysed variables, the correlation matrixes are presented in Table 4. In this regard, the $\mathrm{CO}_{2}$ emissions indicator is highly positive bivariate correlated with all investigated variables except urban population. Likewise, fiscal policy is also positively interrelated with all concerned variables except for urban population and the labour force. However, urban population is found to be adversely correlated with all indicators except trade openness and gross capital formation.

Table 4. Correlation matrix.

\begin{tabular}{|c|c|c|c|c|c|c|c|c|c|}
\hline Variables & $\mathrm{LCO}_{2}$ & LFP & LTGL & LFDI & LFD & LTRD & LURP & LLF & LGCF \\
\hline $\mathrm{LCO}_{2}$ & 1.0000 & & & & & & & & \\
\hline LFP & $\begin{array}{c}0.2123 \\
{[11.566]} \\
(0.0000)\end{array}$ & $\underline{1.0000}$ & & & & & & & \\
\hline LTGL & $\begin{array}{c}0.6677 \\
{[47.748]} \\
(0.0000)\end{array}$ & $\begin{array}{c}0.3926 \\
{[22.726]} \\
(0.0000)\end{array}$ & $\stackrel{1.0000}{-}$ & & & & & & \\
\hline LFDI & $\begin{array}{c}0.5705 \\
{[36.981]} \\
(0.0000)\end{array}$ & $\begin{array}{c}0.1622 \\
{[8.7506]} \\
(0.0000)\end{array}$ & $\begin{array}{c}0.7028 \\
{[53.410]} \\
(0.0000)\end{array}$ & $\begin{array}{l}1.0000 \\
- \\
-\end{array}$ & & & & & \\
\hline LFD & $\begin{array}{c}0.4008 \\
{[23.285]} \\
(0.0000)\end{array}$ & $\begin{array}{c}0.2614 \\
{[14.419]} \\
(0.0000)\end{array}$ & $\begin{array}{c}0.5404 \\
{[34.193]} \\
(0.0000)\end{array}$ & $\begin{array}{c}0.3912 \\
{[22.639]} \\
(0.0000)\end{array}$ & $\frac{1.0000}{-}$ & & & & \\
\hline LTRD & $\begin{array}{c}0.1887 \\
{[10.231]} \\
(0.0000)\end{array}$ & $\begin{array}{c}0.2425 \\
{[13.366]} \\
(0.0000)\end{array}$ & $\begin{array}{c}0.2286 \\
{[12.499]} \\
(0.0000)\end{array}$ & $\begin{array}{c}-0.0059 \\
{[-0.3143]} \\
(0.7533)\end{array}$ & $\begin{array}{c}-0.0289 \\
{[-3.5434]} \\
(0.0000)\end{array}$ & $\frac{1.0000}{-}$ & & & \\
\hline LURP & $\begin{array}{c}-0.3674 \\
{[-21.026]} \\
(0.0000)\end{array}$ & $\begin{array}{c}-0.2326 \\
{[-12.733]} \\
(0.0000)\end{array}$ & $\begin{array}{c}-0.3889 \\
{[-22.474]} \\
(0.0000)\end{array}$ & $\begin{array}{c}-0.2757 \\
{[-15.267]} \\
(0.0000)\end{array}$ & $\begin{array}{c}-0.2188 \\
{[-11.937]} \\
(0.0000)\end{array}$ & $\begin{array}{c}0.0109 \\
{[6.5845]} \\
(0.0000)\end{array}$ & $\frac{1.0000}{-}$ & & \\
\hline LLF & $\begin{array}{c}0.0863 \\
{[4.6121]} \\
(0.0000)\end{array}$ & $\begin{array}{c}-0.2311 \\
{[-12.647]} \\
(0.0000)\end{array}$ & $\begin{array}{c}0.1498 \\
{[8.0676]} \\
(0.0000) \\
\end{array}$ & $\begin{array}{c}0.4869 \\
{[29.677]} \\
(0.0000)\end{array}$ & $\begin{array}{c}0.1734 \\
{[9.3760]} \\
(0.0000)\end{array}$ & $\begin{array}{c}-0.4591 \\
{[-27.512]} \\
(0.0000)\end{array}$ & $\begin{array}{c}-0.1101 \\
{[-5.9004]} \\
(0.0000)\end{array}$ & $\frac{1.0000}{-}$ & \\
\hline LGCF & $\begin{array}{c}0.1147 \\
{[6.1493]} \\
(0.0000)\end{array}$ & $\begin{array}{c}0.0291 \\
{[1.5546]} \\
(0.1201)\end{array}$ & $\begin{array}{c}0.0627 \\
{[3.3475]} \\
(0.0008)\end{array}$ & $\begin{array}{c}0.1251 \\
{[6.7069]} \\
(0.0000)\end{array}$ & $\begin{array}{c}0.0634 \\
{[3.3825]} \\
(0.0007)\end{array}$ & $\begin{array}{c}0.1266 \\
{[6.7953]} \\
(0.0000)\end{array}$ & $\begin{array}{c}0.0823 \\
{[4.3975]} \\
(0.0000)\end{array}$ & $\begin{array}{c}0.1794 \\
{[4.0371]} \\
(0.0000)\end{array}$ & $\stackrel{1.0000}{-}$ \\
\hline
\end{tabular}




\subsection{Results of Panel Unit Root Tests}

Four different panel unit root tests such as LLC, IPS, F-ADF, and F-PP are applied to investigate the stationarity level of the candidate variables/series. The empirical findings of these unit root tests are presented in Table 5. These panel stationary test results reveal that all of the level $\mathrm{I}(0)$ values of these variables are panel unit root except trade openness and foreign direct investment and gross capital formation. However, all these unit root tests of the first difference $\mathrm{I}(1)$ refuse the mutually null hypothesis $\left(\mathrm{H}_{0}\right)$ at a $1 \%$ level of significance. This shows that all concerned variables are stationary at a 1 st difference. The $\left(\mathrm{H}_{0}\right)$ was rejected, which means that there is a unit root problem, and the alternative hypothesis $\left(\mathrm{H}_{1}\right)$ was accepted, which means that there is no unit root to support the first-order stationarity implications. Based on such findings, we precede our empirical analysis to test the long-run cointegration among variables.

Table 5. Results of panel unit root tests.

\begin{tabular}{|c|c|c|c|c|c|c|c|c|}
\hline \multirow[b]{2}{*}{ Variables } & \multicolumn{2}{|c|}{ LLC } & \multicolumn{2}{|c|}{ IPS } & \multicolumn{2}{|c|}{ F-ADF } & \multicolumn{2}{|c|}{ F-PP } \\
\hline & Stats. & Prob. & Stats. & Prob. & Stats. & Prob. & Stats. & Prob. \\
\hline \multicolumn{9}{|c|}{ Level (Intercept and trend) } \\
\hline $\mathrm{LCO}_{2}$ & -0.65089 & 0.3871 & -0.73300 & 0.2318 & 216.058 & 0.3725 & 141.052 & 0.7217 \\
\hline LFP & -0.00518 & 0.6443 & -1.8809 & 0.1463 & 204.410 & 0.2188 & 102.936 & 0.8355 \\
\hline LTGL & -1.98728 & 0.3263 & 1.29468 & 0.9023 & 192.859 & 0.2394 & 161.674 & 0.5214 \\
\hline LFDI & $-5.53230 * * *$ & 0.0000 & 0.68817 & 0.9521 & $296.539 * * *$ & 0.0001 & $506.880 * * *$ & 0.0000 \\
\hline LFD & 3.58481 & 0.9998 & -0.18932 & 0.7645 & 88.2352 & 0.7836 & 67.1559 & 0.9962 \\
\hline LTRD & $-3.56939 * * *$ & 0.0000 & $-3.85931^{* * *}$ & 0.0000 & $343.679 * * *$ & 0.0000 & $333.830 * * *$ & 0.0000 \\
\hline LURP & $2.2 \times 10^{8}$ & 1.0000 & -1.28878 & 0.1195 & $367.402 * * *$ & 0.0000 & $346.810 * * *$ & 0.0000 \\
\hline LLF & 1.80435 & 0.7862 & -0.15341 & 0.7139 & 153.830 & 0.2847 & 213.369 & 0.1533 \\
\hline LGCF & -0.67731 & 0.2491 & $-5.44384^{* * *}$ & 0.0000 & $320.285 * * *$ & 0.0000 & $450.360^{* * *}$ & 0.0000 \\
\hline \multicolumn{9}{|c|}{ First Difference (Intercept only) } \\
\hline $\mathrm{LCO}_{2}$ & $-17.7637^{* * *}$ & 0.0000 & $-25.1492^{* * *}$ & 0.0000 & $1015.24^{* * *}$ & 0.0000 & $1898.21^{* * *}$ & 0.0000 \\
\hline LFP & $-23.6463^{* * *}$ & 0.0000 & $-28.7840^{* * *}$ & 0.0000 & $1164.17^{* * *}$ & 0.0000 & $1996.12 * * *$ & 0.0000 \\
\hline LTGL & $-15.4499^{* * *}$ & 0.0000 & $-20.5946^{* * *}$ & 0.0000 & $836.683 * * *$ & 0.0000 & $1484.85^{* * *}$ & 0.0000 \\
\hline LFDI & $-55.0309 * * *$ & 0.0000 & $-54.0598^{* * *}$ & 0.0000 & $2138.94^{* * *}$ & 0.0000 & $2363.50 * * *$ & 0.0000 \\
\hline LFD & $-33.6540^{* * *}$ & 0.0000 & $-35.2921^{* * *}$ & 0.0000 & $1452.82 * * *$ & 0.0000 & $1549.49 * * *$ & 0.0000 \\
\hline LTRD & $-29.4918^{* * *}$ & 0.0000 & $-29.0033^{* * *}$ & 0.0000 & $1147.44^{* * *}$ & 0.0000 & $1844.44^{* * *}$ & 0.0000 \\
\hline LURP & $3.4 \times 10^{8}$ & 1.0000 & $-19.6390^{* * *}$ & 0.0000 & $800.199 * * *$ & 0.0000 & $1113.88^{* * *}$ & 0.0000 \\
\hline LLF & $-9.36101 * * *$ & 0.0000 & $-18.6859^{* * *}$ & 0.0000 & $784.138^{* * *}$ & 0.0000 & $1326.48^{* * *}$ & 0.0000 \\
\hline LGCF & $-22.2136^{* * *}$ & 0.0000 & $-27.8403^{* * *}$ & 0.0000 & $1131.70^{* * *}$ & 0.0000 & $1883.46^{* * *}$ & 0.0000 \\
\hline
\end{tabular}

Note. ${ }^{* * *}$ and ${ }^{* *}$ indicate the level of significance at $1 \%$ and $5 \%$, respectively.

\subsection{Results of Panel Cointegration Tests}

Based on the panel stationary findings, this study applied the two different panel long-run cointegration tests (Johansen and Kao) to check the long-run association among these variables. The empirical outcomes of these tests are expressed in Table 6. The findings of the Johansen cointegration test recommend that a strong cointegrated relationship exists among the candidate variables in all eight series. Furthermore, the Kao cointegration test was applied as an extra certification to obtain strong and solid evidence for a longrun cointegration relationship at the second strand of Table 6 . The findings detect that the strong long-run cointegration among the series was verified. After discovering the cointegration among variables, the very next step is to estimate the long-run elasticity estimates through various tests. 
Table 6. Results of Johansen Fisher and Kao cointegration test.

\begin{tabular}{|c|c|c|c|c|}
\hline Hypothesized & Fisher Stat. * & & Fisher Stat. * & \\
\hline No. of CE(s) & (from Trace Test) & Prob. & (from Max Eigen Test) & Prob. \\
\hline None & 1442.0 & 0.0000 & 1612.0 & 0.0000 \\
\hline At most 1 & 3266.0 & 0.0000 & 1098.0 & 0.0000 \\
\hline At most 2 & 1899.0 & 0.0000 & 1899.0 & 0.0000 \\
\hline At most 3 & 5507.0 & 0.0000 & 2857.0 & 0.0000 \\
\hline At most 4 & 3547.0 & 0.0000 & 1874.0 & 0.0000 \\
\hline At most 5 & 2212.0 & 0.0000 & 1157.0 & 0.0000 \\
\hline At most 6 & 1292.0 & 0.0000 & 735.90 & 0.0000 \\
\hline At most 7 & 810.80 & 0.0000 & 612.50 & 0.0000 \\
\hline At most 8 & 572.80 & 0.0000 & 572.80 & 0.0000 \\
\hline \multicolumn{2}{|c|}{ Kao Test Statistics } & \multicolumn{2}{|r|}{ t-Statistic } & Prob. \\
\hline \multicolumn{2}{|c|}{ ADF } & \multicolumn{2}{|r|}{-5.599249} & 0.0000 \\
\hline \multicolumn{2}{|c|}{ Residual variance } & \multicolumn{2}{|r|}{0.131422} & \\
\hline
\end{tabular}

Note. Automatic lag length selection based on SIC with a max lag of 6, Newey-West automatic bandwidth selection, and Bartlett kernel. * Probabilities are computed using asymptotic Chi-square distribution.

\subsection{Results of Panel Long-Run Elasticity Estimates}

In order to estimate the long-run elasticity of concerned variables (e.g., LFP, LTGL, LFDI, LFD, LTRD, LURP, LLF, and LGCF), this study applied three different panel long-run elasticity estimation approaches such as the FMOLS, DOLS, and PMG/ARDL methods. These tests are robust for tackling the problem of autocorrelation, heteroscedasticity, and endogeneity problems. However, we select the FMOLS estimator on the basis of high R-squared (goodness of fits) values and minimum long-run variance. The findings of all estimation approaches are presented in Table 7.

Table 7. Long-run elasticity estimates (FMOLS, DOLS, and ARDL).

\begin{tabular}{|c|c|c|c|c|c|c|c|c|c|c|c|c|}
\hline \multirow{2}{*}{ Variable } & \multicolumn{4}{|c|}{ Full Modified Least Squares (FMOLS) } & \multicolumn{4}{|c|}{ Dynamic Least Squares (DOLS) } & \multicolumn{4}{|c|}{ Autoregressive Distributed Lag (ARDL) } \\
\hline & Coeff. & Std. Err. & t-Stat. & Prob. & Coeff. & Std. Err. & t-Stat. & Prob. & Coeff. & Std. Err. & t-Stat. & Prob. \\
\hline LFP & 0.0017 * & 0.0008 & 2.0482 & 0.0406 & 0.0266 * & 0.0032 & 6.3052 & 0.0000 & $0.0193 *$ & 0.0018 & 10.5689 & 0.0000 \\
\hline LTGL & 0.6036 * & 0.1046 & 5.7668 & 0.0000 & $0.5879 *$ & 0.0547 & 5.2186 & 0.0000 & $0.9787 *$ & 0.1123 & 8.7122 & 0.0000 \\
\hline LFDI & 0.0204 * & 0.0032 & 6.2712 & 0.0000 & $0.1468 *$ & 0.0158 & 9.2905 & 0.0000 & 0.1014 * & 0.0096 & 10.5008 & 0.0000 \\
\hline LFD & $0.0446 *$ & 0.0116 & 3.8362 & 0.0001 & $0.0791 * *$ & 0.0326 & 2.4218 & 0.0156 & $0.4592 *$ & 0.0309 & 14.8196 & 0.0000 \\
\hline LTRD & $-0.0629 *$ & 0.0235 & -2.6615 & 0.0078 & $-0.2594 *$ & 0.0489 & -3.2139 & 0.0000 & -0.7733 * & 0.0414 & -18.6657 & 0.0000 \\
\hline LURP & $-0.2582 *$ & 0.0288 & -9.2180 & 0.0000 & $-0.0869 *$ & 0.0287 & -3.0963 & 0.0020 & -0.1598 * & 0.0265 & -6.0067 & 0.0000 \\
\hline LLF & -0.1358 * & 0.0293 & -4.6341 & 0.0000 & $-0.0762 *$ & 0.0252 & -3.0454 & 0.0024 & -0.3527 * & 0.0123 & -28.3524 & 0.0000 \\
\hline LGCF & 0.1661 * & 0.0182 & 9.1281 & 0.0000 & $0.4406^{*}$ & 0.0869 & 5.0684 & 0.0000 & $0.3652 *$ & 0.0724 & 5.0384 & 0.0000 \\
\hline \multicolumn{2}{|c|}{ R-squared } & \multicolumn{3}{|c|}{0.990386} & \multicolumn{4}{|c|}{0.927735} & \multirow{4}{*}{\multicolumn{2}{|c|}{$\begin{array}{l}\text { Log likelihood } \\
\text { Akaike info criterion } \\
\text { Schwarz criterion } \\
\text { Hannan-Quinn } \\
\text { criterion }\end{array}$}} & \multicolumn{2}{|c|}{3933.757} \\
\hline \multicolumn{2}{|c|}{ Adjusted R-squared } & \multicolumn{3}{|c|}{0.898407} & \multicolumn{4}{|c|}{0.797611} & & & \multicolumn{2}{|c|}{-2.028752} \\
\hline \multirow{2}{*}{\multicolumn{2}{|c|}{$\begin{array}{l}\text { Long-run variance } \\
\text { Mean of dependent } \\
\text { variable }\end{array}$}} & \multicolumn{3}{|c|}{0.009471} & \multicolumn{4}{|c|}{0.138633} & & & \multicolumn{2}{|c|}{0.191666} \\
\hline & & \multicolumn{3}{|c|}{0.860372} & \multicolumn{4}{|c|}{0.844781} & & & \multicolumn{2}{|c|}{-1.227773} \\
\hline \multirow{2}{*}{\multicolumn{2}{|c|}{$\begin{array}{l}\text { S.E. of regression } \\
\text { S.D. dependent } \\
\text { variable }\end{array}$}} & \multicolumn{3}{|c|}{1.324234} & \multicolumn{4}{|c|}{0.683089} & \multicolumn{4}{|c|}{0.114583} \\
\hline & & \multicolumn{3}{|c|}{1.507546} & \multicolumn{4}{|c|}{1.518392} & \multicolumn{4}{|c|}{0.133869} \\
\hline \multicolumn{2}{|c|}{ Sum squared residual } & \multicolumn{3}{|c|}{4773.289} & \multicolumn{4}{|c|}{433.0149} & \multicolumn{4}{|c|}{23.33059} \\
\hline
\end{tabular}

Note. ${ }^{*}$ and ${ }^{* *}$ denote the significance level at $1 \%$ and $5 \%$, respectively.

The findings of the FMOLS approach show that fiscal policy has a positive and significant impact on $\mathrm{CO}_{2}$ emissions in the long run. Specifically, the marginal impact of fiscal policy on carbon emissions is $0.0017 \%$ in the long run. This reveals that the fiscal policy of each and every country increases $\mathrm{CO}_{2}$ emissions in the world panel countries. However, the marginal impact of fiscal policy is much lower as compared to all other indicators. In addition, this finding is consistent with those of Yuelan et al. [76], who showed the positive relationship between fiscal policy and $\mathrm{CO}_{2}$ emission. In this pursuit, López et al. [4] investigated that there are many channels of fiscal policy that may affect environmental quality. It depends on the relationship between fiscal policy and economic growth; government spending may lead to an increase in pollution in some levels of 
economic growth. In this detection, human capital and energy-efficient projects (educated and skilled labour) are not dominant factors in these countries. The dominant factor of public spending in these countries may have pollution haven technology. A more likely elucidation is that these countries have been endeavouring to acquire long-term sustainable economic growth/development along with addressing the unemployment demand, etc. Moreover, these world economies have experienced severe trouble regarding consumption, their production and real income growth since the recession period (2007-2009). For that reason, fiscal policy is espoused in world economies by increasing expenditure to the promotion of the industrial sector, increasing per capita aggregate domestic consumption, and cutting taxes, which reduces the overall unemployment rate [16]. An increase in the demand side puts huge pressure on the supply-side production process to congregate the excessive demand. If the investors have no ability to enhance the production level instantly, they are more likely to inflate the prices. As a result, this shows that an increase in industrial sector production owing to the upsurge in per capita aggregate domestic consumption resulted in the promotion of environmental degradation. Another prospect is that new investors have chosen to venture into conventional, cheap, and traditional energy sources instead of investment in alternative, clean, and renewable energy sources at some point during the economic recession; consequently, a high ratio of environmental degradation will occur. Therefore, government expenditure increases the environmental pollution in the region. On the contrary, government spending is associated with the education and health sectors of labour because better health and technical education (efficient human capital) will be very helpful to control environmental pollution [77]. This mechanism has focussed government spending on the physical capital-intensive mean. The poor institutional quality might be a big reason; further, these countries are not able to enhance their environmental settings because environmental plans have long-run outcomes and government spending is mostly owed to the projects with short-run tangible returns.

During a turn of the globalization process, it has a positive and significant impact on $\mathrm{CO}_{2}$ emissions in the world panel countries. More specifically, a $1 \%$ increase in globalization will lead to an increase in the global pollution level by $0.6036 \%$ in the long run. This suggests that the globalization process tends to increase $\mathrm{CO}_{2}$ emissions, therefore putting greater pressure on the environment. These findings are similar to the outcomes explored by Yang et al. [78] and Pata [79] in contrast with the findings of Jahanger et al. [80,81]. One reason might be that globalization deteriorates environmental performance in these countries because these sample countries do not import and use eco-friendly (energy-saving production) technologies and have less strict environmental rules and regulations; while enhancing maximum growth for profit-making drives, they will crumble environmental health through discharging $\mathrm{CO}_{2}$ emissions into the atmosphere [82]. Moreover, these countries changed their production processes from the industrial to the service sector. The service sector exhibits less energy utilization due to the use of eco-friendly and energyefficient technologies from the developed countries through foreign direct investment or international trade. Considering this view, the coefficient sign of foreign direct investment also had a positive and significant level of significance at $1 \%$. This result shows that a $1 \%$ increase in foreign direct investment will lead to an increase of $0.020 \%$ in $\mathrm{CO}_{2}$ emissions and conforms to the existence of the pollution haven hypothesis in these panel countries. This result is in line with the conclusion of Balsalobre-Lorente et al. [39], who found a positive and significant association between foreign direct investment and $\mathrm{CO}_{2}$ emissions in the MINT countries. These countries sacrifice environmental rules and regulations to attract more foreign direct investment and encourage economic growth such as "race to the bottom" in the long run. The policymakers of these countries should encourage/attract foreign investors only in the environmental sustainability sectors (pollution-free industries), which brings eco-friendly technologies, skills, and methods.

Regarding the coefficient of financial development, it also explores a positive and significant effect on $\mathrm{CO}_{2}$ emissions. More specifically, a $1 \%$ enhancement in financial development will lead to an increase in $\mathrm{CO}_{2}$ emissions by $0.044 \%$ in the long run. These 
outcomes are consistent with the findings of Usman et al. [83] and Jiang and Ma [84]. One reason for the increase in pollution level is that financial development promotes infrastructure projects (i.e., building, roads) by providing long-term loans, which promote $\mathrm{CO}_{2}$ emissions. Another possible reason could be that financial development enhances the purchasing power of the public by giving cheap loans, thus increasing the purchase of luxury goods such as automobiles that, in turn, put more pressure on the environment. On the contrary, trade openness has a negative and significant impact on $\mathrm{CO}_{2}$ emissions. Particularly, a 1\% augmentation in trade openness will cause a decrease in environmental degradation of $0.062 \%$ in the long run. This finding is consistent with the outcomes explored by Al-Mulali et al. [29] and Farhani et al. [85]. These studies found that trade openness significantly reduce the pressure on the environment. Most of these economies mainly imported energy-efficient and eco-friendly commodities such as first-hand products. At the same time, these goods and products improve the environmental quality and economic development in the long run, as well as their corresponding increase in renewable and green energy consumption. The suggestion is that trade openness could also come along with advanced methods of production that encourage a favourable environment. This indicates the presence of the pollution halo effect, where knowledge overflow from appealing with industrialized countries promotes cleaner and green growth in domestic economies by reducing carbon emissions that ultimately, increase the quality of environment eminence.

Similarly, the urban population also exerts a negative impact on $\mathrm{CO}_{2}$ emissions in the world panel countries. Particularly, a 1\% increase in urban population will minimize $\mathrm{CO}_{2}$ emissions by $0.258 \%$ in the long run. This finding is similar to the results explored by Yang et al. [86]. The possible reasons for the adverse effect of urban population on environmental degradation are as follows, for instance, when the level of urban population is increased, the rural population moves from rural to urban areas to attain better education or skill, as a result improving the human capital, and most of the population will prefer a clean environment with a lower emissions level. Moreover, the labour force has an adverse effect on $\mathrm{CO}_{2}$ emissions in the long run. More specifically, a $1 \%$ boost in labour force will lead to a $0.135 \%$ reduction in $\mathrm{CO}_{2}$ emissions in the region. This is due to the fact that when the demand for labour force increases because of more industrial activities, production processes that need more energy resources are elevated. In this regard, most of the energy sources in these countries are based on non-renewable fossil fuel energy consumption. One other reason for the positive impact of the labour force on carbon emissions is that the labour of these countries is not well educated regarding environmental protection. Therefore, this will ultimately exert huge pressure on the environment. This finding is consistent with the findings of Wang et al. [87]. In contrast, gross capital formation confirmed the positive influence on $\mathrm{CO}_{2}$ emissions. Particularly, a $1 \%$ increase in gross capital formation will lead to an enhancement in $\mathrm{CO}_{2}$ emissions by $0.1661 \%$ in the long run, and these outcomes are consistent with the previous study by Etokakpan et al. [88]. This finding indicates that in these countries, higher per labour resources and their associated capital are not reliable with energy-proficient and eco-friendly green technologies, as Ling et al. [89] observed that higher gross fixed capital per unit of labour has some ability to protect environmental quality if it is directly linked with energy-efficient and environmentally friendly green technologies. Additionally, Figure 4 shows the actual, fitted, and estimated terms of $\mathrm{CO}_{2}$ emissions by $\mathrm{LCO}_{2}=\mathrm{f}$ (LFP, LTGL, LFDI, LFD, LTRD, LURP, LLF, and LGCF) for global panel countries in the long run.

For robustness checks, the current study applied alternative techniques (e.g., DOLS and PMG/ARDL). The empirical analysis explores that LFP, LTGL, LFDI, LFD, and LGCF significantly increase environmental pollution, while LTRD, LURP, and LLF reduce it in the region. These findings are consistent with our earlier estimation approaches such as FMOLS. Hence, our results with alternative methods are robust and reliable, which ensures the accuracy of our main findings. 


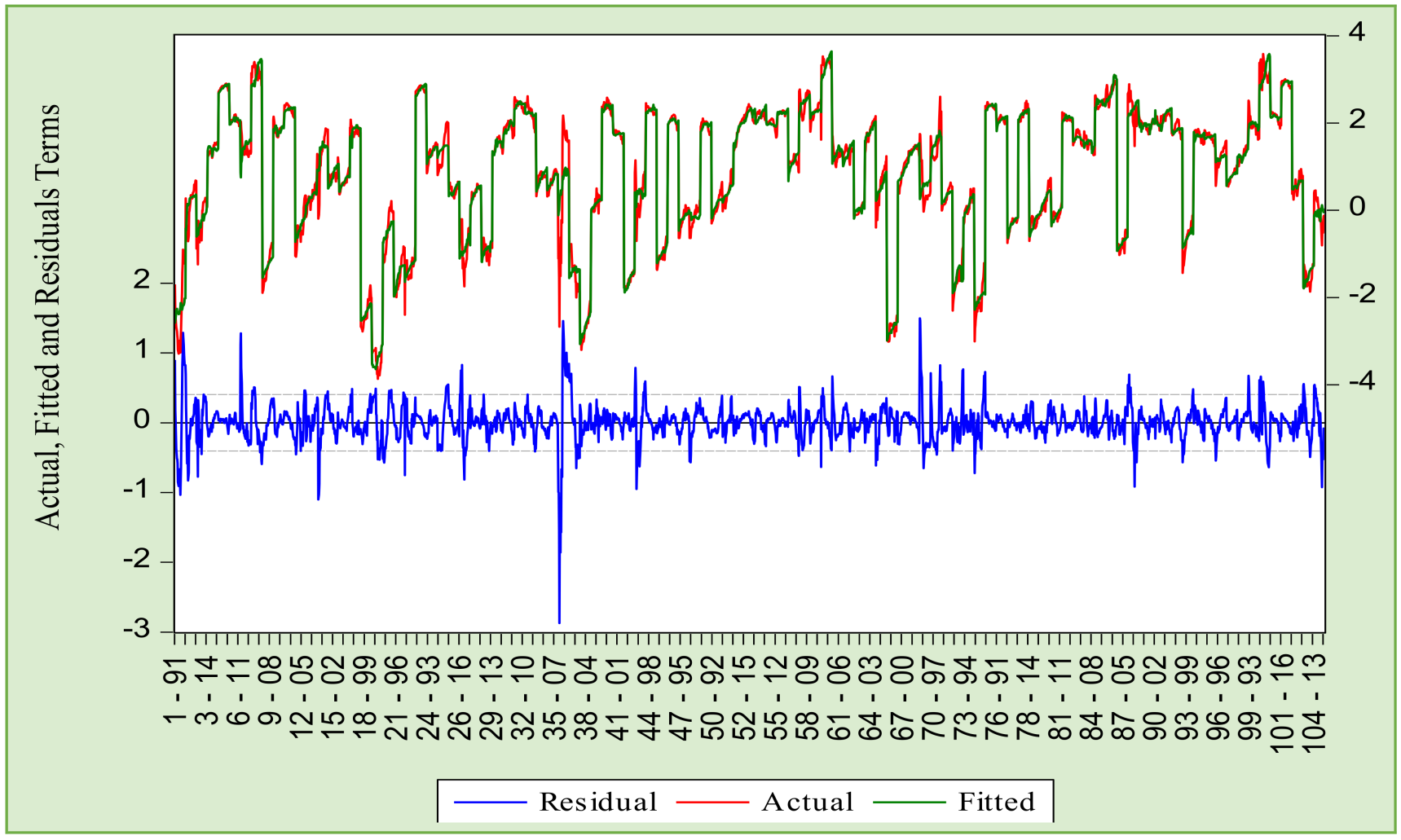

Figure 4. Actual, fitted, and estimated terms of $\mathrm{CO}_{2}$ emissions by $\mathrm{LCO}_{2}=\mathrm{f}(\mathrm{LFP}, \mathrm{LTGL}, \mathrm{LFDI}, \mathrm{LFD}, \mathrm{LTRD}, \mathrm{LURP}, \mathrm{LLF}$, and LGCF).

The investigation for the short-term effects of regressors on explained variables is reported in Table 8 . This explores the findings of short-term coefficient/elasticity of $\mathrm{CO}_{2}$ emissions with respect to LFP, LTGL, LFDI, LFD, LTRD, LURP, LLF, and LGCF in the world panel countries. Considering this view, COINTEQ01, which shows the error correction mechanism (ECM), explores the speed of percentage convergence to equilibrium from the short term to the long term per year. Furthermore, the panel ECM sign was significant and negative and explores a $43.1902 \%$ adjustment in $\mathrm{CO}_{2}$ emissions from the short-run to long-run equilibrium annually. Particularly, in order to achieve long-term equilibrium, this shows that the world panel countries will need 2.315 years. Moreover, short-run outcomes demonstrate that a $1 \%$ change in the lag of $\mathrm{CO}_{2}$ emissions will cause an increase in the environmental pollution level by $0.000129 \%$ in the world panel countries. Similarly, the short-run impact of gross capital formation will significantly increase the pollution level by $0.105450 \%$. In contrast, the empirical findings of trade openness and urban population have a statistically significant and adverse impact on $\mathrm{CO}_{2}$ emissions in the short term. More specifically, a $1 \%$ influence in trade openness and urban population tends to reduce the environmental pressure by $0.073211 \%$ and $0.148159 \%$, respectively. However, all other carbon determinants are found to be statistically insignificant in the short term.

Table 8. Results of ARDL-based short-run elasticity estimates (ARDL $(2,1,1,1,1,1,1,1,1)$ ).

\begin{tabular}{ccccc}
\hline Variables & Coefficient & Std. Error & t-Statistics & Prob. ${ }^{*}$ \\
\hline COINTEQ01 & $-0.431902^{*}$ & 0.014800 & -3.831271 & 0.0000 \\
D(LCO2(-1)) & $-0.078158^{*}$ & 0.028397 & -2.752280 & 0.0060 \\
D(LFP) & 0.000129 & 0.001370 & 0.094115 & 0.9250 \\
D(LTGL) & 0.210432 & 0.191473 & 1.099019 & 0.2719 \\
\hline
\end{tabular}


Table 8. Cont.

\begin{tabular}{ccccc}
\hline Variables & Coefficient & Std. Error & t-Statistics & Prob. ${ }^{*}$ \\
\hline D(LFDI) & $5.06 \times 10^{-5}$ & 0.004113 & 0.012300 & 0.9902 \\
D(LFD) & 0.013383 & 0.020152 & 0.664082 & 0.5067 \\
D(LTRD) & $-0.073211^{* * *}$ & 0.042288 & -1.731229 & 0.0836 \\
D(LURP) & $-0.148159^{* * *}$ & 0.080229 & -1.846695 & 0.0650 \\
D(LLF) & 0.067043 & 0.248327 & 0.269980 & 0.7872 \\
D(LGCF) & $0.105450^{*}$ & 0.030123 & 3.500670 & 0.0005 \\
\hline
\end{tabular}

Note. ${ }^{*}$ and ${ }^{* * *}$ denote the significance level at $1 \%$ and $10 \%$, respectively.

\subsection{Identifying the Threshold Level}

In order to examine the panel threshold approach as developed by Hansen $[74,75]$, this study has applied the bootstrap technique, which permits the structure of a confidence interval and evaluation of the statistical consequence of the threshold level identified. Therefore, we first estimated the single and multiple threshold models and, interestingly, found a single threshold to be significant at the $1 \%$ level, while two and three thresholds appeared to be insignificant. For the single threshold, we found a significant value at the $1 \%$ level. This finding implies the nexus between fiscal policy and $\mathrm{CO}_{2}$ emission. The threshold point of -1.2889 is critical and specifies a turning point at which level the effect of fiscal policy on $\mathrm{CO}_{2}$ emission is significant. The findings present important policy implementations for policymakers and regulatory authorities to maintain a minimum point of fiscal policy at -1.2889 in order to obtain more positive advantages of fiscal policy, because when fiscal policy drops under this level, it could have a negative effect on $\mathrm{CO}_{2}$ emissions. To be more specific, governments need to pay serious attention to increasing fiscal policy above the -1.2889 threshold level. Figure 5 graphically illustrates the threshold regression. The relevant results and statistics of the threshold are presented in Tables 9 and 10, respectively.

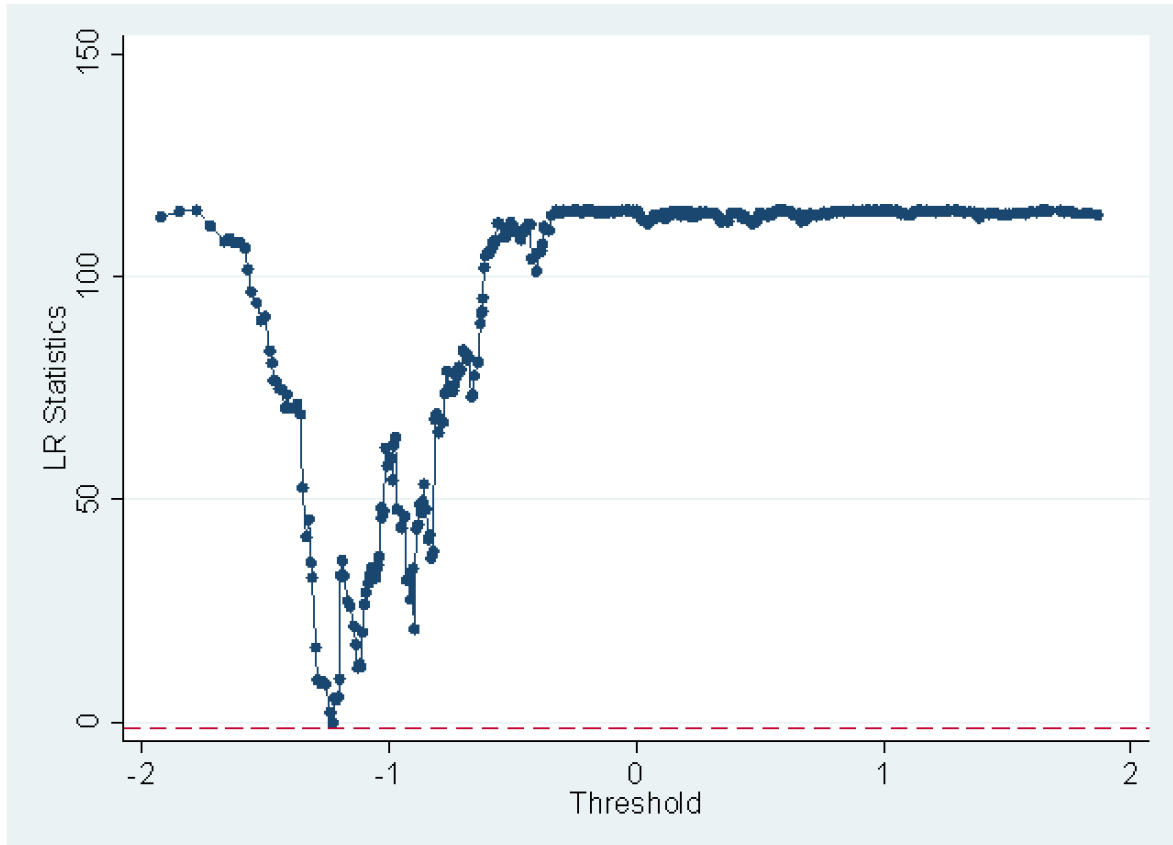

Figure 5. Confidence interval structure for a single-threshold model. 
Table 9. Threshold effect test estimations.

\begin{tabular}{cccc}
\hline & Single Threshold & Double Threshold & Triple Threshold \\
\hline F-statics & 115.21 & 23.63 & 17.63 \\
$p$-value & 0.0000 & 0.246 & 0.322 \\
\hline Critical Values & & & \\
\hline $10 \%$ & 36.2299 & 32.1352 & 27.6806 \\
$5 \%$ & 42.5525 & 37.9405 & 33.6307 \\
$1 \%$ & 61.0479 & 51.8926 & 51.7746 \\
\hline Bootstrap Repeat & 500 & 500 & 500 \\
\hline
\end{tabular}

Table 10. Threshold estimations.

\begin{tabular}{ccc}
\hline Threshold Value & \multicolumn{2}{c}{$95 \%$ Confidence Interval } \\
\hline & Lower Value & Upper Value \\
\hline-1.2289 & -1.2485 & -1.2213 \\
\hline
\end{tabular}

\section{Conclusions and Policy Implications}

In this article, we have investigated the impact of fiscal policy, globalization, financial development, trade openness, urban population, gross capital formation, labour force, and foreign direct investment on $\mathrm{CO}_{2}$ emissions using data from the global sample of 105 countries from 1990 to 2016 by identifying linear and nonlinear estimates through FMOLS and panel threshold estimator. First of all, four stationarity tests such as LLC, IPS, ADF, and PP were applied to measure the stationarity among the variables, and two cointegration approaches were implemented to sketch the cointegration associations among the candidate variables. The cointegration assessments suggested the use of the DOLS, FMOLS, and PMG/ARDL approaches in these economies.

According to the empirical outcomes, we concluded that fiscal policy and globalization could increase $\mathrm{CO}_{2}$ emissions from a global perspective. Further, we concluded that foreign direct investment increases $\mathrm{CO}_{2}$ emissions, which supports the validity of the pollution haven hypothesis in the region. In addition, this paper applies a panel threshold to conclude a benchmark of -1.2289 beyond which the effect of fiscal policy on $\mathrm{CO}_{2}$ emissions becomes negative. Moreover, our robustness checks confirmed that the above empirical findings are reliable. This finding carries useful implications for governments, policymakers, and regularity authorities. The empirical analysis of this study recommends the following policy implications:

Fiscal spending on the education, health, research, and development sectors boosts up the consumer's current and future income, which may lead to deterioration of environmental quality through the income growth channel. A higher level of government expenditure aiding the development, enforcement, and effectiveness of environmental regulations may lead to the enforcement of institutions, improving environmental quality through the environmental regulation channel. Public spending in the public transportation sector (green energy) may reduce pollution and be less environmentally damaging compared to the use of public transportations. Further, there is a need to design industrial- and macroeconomic-level policies to support the implementation of low-energy-intensive and lower carbon production technologies. Furthermore, the government should bring strict rules and regulations to both foreign and domestic firms to implement an environmentally friendly manufacturing structure. This study also recommends that the governments of these countries should encourage exporter industries to increase their usage of renewable energy and efficient energy usage. In addition, the incentive should be given to touristic hotels and tourism companies to boost up the share of renewable energy consumption within the energy mix usage. 
Governments should transform the structure of local financial expenditure, promote economic development, and upgrading the industrial sector. On the one hand, the financial expenditure of economic construction plays the guiding role of adjusting the industrial structure; it is necessary to convert the inefficient production methods of the secondary industry to guide low value-added, high-energy consumption, and at the same time, enterprises with high value-added and high human capital are introduced, and enterprises with low pollution are used to improve the production efficiency of the secondary industry. On the other hand, it is necessary to appropriately increase expenditure on social services such as science, education, culture, and health as well as improving scientific research and development, such as research and development of energy saving, environmental protection, and improving the production efficiency of low-energy-consumption technologies, while protecting the environment. Second, it is necessary to increase investment in research and development (R\&D) and improve the utilization rate of funds; tax incentives and tax reductions should be used to encourage pollution control enterprises to adopt environmental protection facilities with high technical content and good pollution control effects, so as to reduce the impact of pollution and decrease the pressure on the environment. Furthermore, there is a need to design industrial- and macroeconomic-level policies to support and highlight the implementation of low-energy-intensive and lower carbon production technologies. Further, the government should bring strict rules and regulations to both foreign and domestic firms to implement an environmentally friendly manufacturing structure.

This study has some limitations, which can be pointed out in future research, since we have not deliberated important variables such as cultural and social variables in our systematic agenda. Future scholars could also extend this empirical study by examining the moderate role of fiscal policy and globalization in the framework of the environmental Kuznets curve (EKC) hypothesis and make a significant contribution to the literature review.

Author Contributions: Conceptualization, M.K., M.U., and A.J.; methodology, M.U.; software, M.U.; validation, M.K., M.U., and D.B.-L.; formal analysis, M.U. and A.J.; investigation, M.K.; resources, M.U. and A.J.; data curation, M.U. and A.J.; writing-original draft preparation, M.U. and A.J.; Revising, writing—review and editing, M.U.; visualization, M.U. and D.B.-L.; supervision, D.B.-L.; project administration, M.U. and M.K. All authors have read and agreed to the published version of the manuscript.

Funding: This research received no external funding.

Institutional Review Board Statement: Not applicable.

Informed Consent Statement: Not applicable.

Data Availability Statement: All data used in this study are publicly available and mentioned in the paper.

Conflicts of Interest: The authors declare no conflict of interest.

Appendix A

Table A1. Lists of countries.

\begin{tabular}{ccccc}
\hline Afghanistan & Cameroon & Georgia & Lithuania & Portugal \\
Albania & Canada & Germany & Madagascar & Romania \\
Angola & Chile & Ghana & Malaysia & Russian Federation \\
Argentina & China & Greece & Maldives & Saudi Arabia \\
Australia & Colombia & Monduras & Mali & Singapore \\
Austria & Congo, Rep. & Hungary & Mexico & South Africa \\
Azerbaijan & Costa Rica & Iceland & Moldova & Spain \\
Bahrain & Cote d'Ivoire & India & & \\
\hline
\end{tabular}


Table A1. Cont.

\begin{tabular}{|c|c|c|c|c|}
\hline Bangladesh & Croatia & Indonesia & Mongolia & Sri Lanka \\
\hline Belarus & Cyprus & Iran, Islamic Rep. & Morocco & Sweden \\
\hline Belgium & Czech Republic & Ireland & Myanmar & Switzerland \\
\hline Bhutan & Denmark & Israel & Namibia & Thailand \\
\hline Bolivia & Dominican Republic & Italy & Nepal & Tunisia \\
\hline $\begin{array}{l}\text { Bosnia and } \\
\text { Herzegovina }\end{array}$ & Egypt, Arab Rep. & Japan & Netherlands & Turkey \\
\hline Botswana & Equatorial Guinea & Jordan & New Zealand & Ukraine \\
\hline Brazil & Estonia & Kazakhstan & Nicaragua & United Arab Emirates \\
\hline Bulgaria & Ethiopia & Korea, Rep. & Norway & United Kingdom \\
\hline Burkina Faso & Fiji & Kuwait & Paraguay & United States \\
\hline Burundi & Finland & Latvia & Peru & Uruguay \\
\hline Cape Verde & France & Lebanon & Philippines & Zambia \\
\hline Cambodia & Gambia & Lesotho & Poland & Zimbabwe \\
\hline
\end{tabular}

Source: World Bank classification [55].

\section{References}

1. Hafeez, M.; Yuan, C.; Yuan, Q.; Zhuo, Z.; Stromaier, D. A global prospective of environmental degradations: Economy and finance. Environ. Sci. Pollut. Res. 2019, 26, 25898-25915. [CrossRef] [PubMed]

2. Burke, P. Fiscal Policies for Development and Climate Action. Bull. Indones. Econ. Stud. 2019, 55, 263-264. [CrossRef]

3. Halkos, G.E.; Paizanos, E.A. The effect of government expenditure on the environment: An empirical investigation. Ecol. Econ. 2013, 91, 48-56. [CrossRef]

4. López, R.; Galinato, G.I.; Islam, A. Fiscal spending and the environment: Theory and empirics. J. Environ. Econ. Manag. 2011, 62, 180-198. [CrossRef]

5. Sarkodie, S.A.; Adams, S.; Owusu, P.A.; Leirvik, T.; Ozturk, I. Mitigating degradation and emissions in China: The role of environmental sustainability, human capital and renewable energy. Sci. Total Environ. 2020, 719, 137530. [CrossRef]

6. Bolat, S.; Emirmahmutoglu, F.; Belke, M. The Dynamic Linkages of Budget Deficits and Current Account Deficits Nexus in EU Countries: Bootstrap Panel Granger Causality Test. Int. J. Econ. Perspect. 2014, 8, 16-26.

7. Islam, A.M.; López, R.E. Government Spending and Air Pollution in the US. International Review of Environmental and Resource Economics. 2014. Available online: https:/ /ageconsearch.umn.edu/record/144406/ (accessed on 19 March 2021).

8. López, R.; Palacios, A. Why has Europe become environmentally cleaner? Decomposing the roles of fiscal, trade and environmental policies. Environ. Resour. Econ. 2014, 58, 91-108. [CrossRef]

9. Farzanegan, M.R.; Feizi, M.; Gholipour, H.F. Globalization and the outbreak of COVID-19: An empirical analysis. J. Risk Financ. Manag. 2021, 14, 105.

10. Blum, B.; Neumärker, B.K. Lessons from Globalization and the COVID-19 Pandemic for Economic, Environmental and Social Policy. World 2021, 2, 308-333. [CrossRef]

11. Wang, X.; Yang, Q.; He, N. Research on the Influence of Environmental Regulation on Social Employment-An Empirical Analysis Based on the STR Model. Int. J. Environ. Res. Public Health 2020, 17, 622. [CrossRef]

12. Zarsky, L. Havens, halos and spaghetti: Untangling the evidence about foreign direct investment and the environment. Foreign Direct Invest. Environ. 1999, 13, 47-74.

13. Bakirtas, I.; Cetin, M.A. Revisiting the environmental Kuznets curve and pollution haven hypotheses: MIKTA sample. Environ. Sci. Pollut. Res. 2017, 24, 18273-18283. [CrossRef]

14. Usman, M.; Kousar, R.; Yaseen, M.R.; Makhdum, M.S.A. An empirical nexus between economic growth, energy utilization, trade policy, and ecological footprint: A continent-wise comparison in upper-middle-income countries. Environ. Sci. Pollut. Res. 2020, 27, 38995-39018. [CrossRef]

15. Ike, G.N.; Usman, O.; Sarkodie, S.A. Fiscal policy and $\mathrm{CO}_{2}$ emissions from heterogeneous fuel sources in Thailand: Evidence from multiple structural breaks cointegration test. Sci. Total Environ. 2020, 702, 134711. [CrossRef]

16. Chishti, M.Z.; Ahmad, M.; Rehman, A.; Khan, M.K. Mitigations pathways towards sustainable development: Assessing the influence of fiscal and monetary policies on carbon emissions in BRICS economies. J. Clean. Prod. 2021, 292, 126035. [CrossRef]

17. Ullah, S.; Ozturk, I.; Sohail, S. The asymmetric effects of fiscal and monetary policy instruments on Pakistan's environmental pollution. Environ. Sci. Pollut. Res. 2021, 28, 7450-7461. [CrossRef]

18. Chan, Y.T. Are macroeconomic policies better in curbing air pollution than environmental policies? A DSGE approach with carbon-dependent fiscal and monetary policies. Energy Policy 2020, 141, 111454. [CrossRef]

19. Jain, V.; Purnomo, E.P.; Islam, M.M.; Mughal, N.; Guerrero, J.W.G.; Ullah, S. Controlling environmental pollution: Dynamic role of fiscal decentralization in $\mathrm{CO}_{2}$ emission in Asian economies. Environ. Sci. Pollut. Res. 2021, 134. [CrossRef]

20. Khan, Z.; Ali, S.; Dong, K.; Li, R.Y.M. How does fiscal decentralization affect $\mathrm{CO}_{2}$ emissions? The roles of institutions and human capital. Energy Econ. 2021, 94, 105060. [CrossRef] 
21. Cheng, S.; Fan, W.; Chen, J.; Meng, F.; Liu, G.; Song, M.; Yang, Z. The impact of fiscal decentralization on $\mathrm{CO}_{2}$ emissions in China. Energy 2020, 192, 116685. [CrossRef]

22. Langarita, R.; Cazcarro, I.; Sánchez-Chóliz, J.; Sarasa, C. The role of fiscal measures in promoting renewable electricity in Spain. Energy Convers. Manag. 2021, 244, 114480. [CrossRef]

23. Tufail, M.; Song, L.; Adebayo, T.S.; Kirikkaleli, D.; Khan, S. Do fiscal decentralization and natural resources rent curb carbon emissions? Evidence from developed countries. Environ. Sci. Pollut. Res. 2021, 28, 49179-49190. [CrossRef]

24. Lv, Z.; Li, S. How financial development affects $\mathrm{CO}_{2}$ emissions: A spatial econometric analysis. J. Environ. Manag. 2021, 277, 111397. [CrossRef]

25. Shen, Y.; Su, Z.W.; Malik, M.Y.; Umar, M.; Khan, Z.; Khan, M. Does green investment, financial development and natural resources rent limit carbon emissions? A provincial panel analysis of China. Sci. Total Environ. 2021, 755, 142538. [CrossRef]

26. Yang, B.; Jahanger, A.; Ali, M. Remittance inflows affect the ecological footprint in BICS countries: Do technological innovation and financial development matter? Environ. Sci. Pollut. Res. 2021, 28, 23482-23500. [CrossRef]

27. Usman, M.; Makhdum, M.S.A.; Kousar, R. Does financial inclusion, renewable and non-renewable energy utilization accelerate ecological footprints and economic growth? Fresh evidence from 15 highest emitting countries. Sustain. Cities Soc. 2020, 65, 102590. [CrossRef]

28. Usman, M.; Anwar, S.; Yaseen, M.R.; Makhdum, M.S.A.; Kousar, R.; Jahanger, A. Unveiling the dynamic relationship between agriculture value addition, energy utilization, tourism and environmental degradation in South Asia. J. Public Aff. 2021, e2712. [CrossRef]

29. Al-Mulali, U.; Ozturk, I.; Lean, H.H. The influence of economic growth, urbanization, trade openness, financial development, and renewable energy on pollution in Europe. Nat. Hazards 2015, 79, 621-644. [CrossRef]

30. Shahbaz, M.; Shahzad, S.J.H.; Ahmad, N.; Alam, S. Financial development and environmental quality: The way forward. Energy Policy 2016, 98, 353-364. [CrossRef]

31. Bekhet, H.A.; Matar, A.; Yasmin, T. $\mathrm{CO}_{2}$ emissions, energy consumption, economic growth, and financial development in GCC countries: Dynamic simultaneous equation models. Renew. Sustain. Energy Rev. 2017, 70, 117-132. [CrossRef]

32. Cetin, M.; Ecevit, E.; Yucel, A.G. The impact of economic growth, energy consumption, trade openness, and financial development on carbon emissions: Empirical evidence from Turkey. Environ. Sci. Pollut. Res. 2018, 25, 36589-36603. [CrossRef] [PubMed]

33. Zafar, M.W.; Saud, S.; Hou, F. The impact of globalization and financial development on environmental quality: Evidence from selected countries in the Organization for Economic Co-operation and Development (OECD). Environ. Sci. Pollut. Res. 2019, 26, 13246-13262. [CrossRef] [PubMed]

34. Dogan, E.; Seker, F. The influence of real output, renewable and non-renewable energy, trade and financial development on carbon emissions in the top renewable energy countries. Renew. Sustain. Energy Rev. 2016, 60, 1074-1085. [CrossRef]

35. Zaidi, S.A.H.; Zafar, M.W.; Shahbaz, M.; Hou, F. Dynamic linkages between globalization, financial development and carbon emissions: Evidence from Asia Pacific Economic Cooperation countries. J. Clean. Prod. 2019, 228, 533-543. [CrossRef]

36. Usman, M.; Hammar, N. Dynamic relationship between technological innovations, financial development, renewable energy, and ecological footprint: Fresh insights based on the STIRPAT model for Asia Pacific Economic Cooperation countries. Environ. Sci. Pollut. Res. 2021, 28, 15519-15536. [CrossRef]

37. Nadeem, A.M.; Ali, T.; Khan, M.T.I.; Guo, Z. Relationship between inward FDI and environmental degradation for Pakistan: An exploration of pollution haven hypothesis through ARDL approach. Environ. Sci. Pollut. Res. 2020, 27, 15407-15425. [CrossRef]

38. Yilanci, V.; Bozoklu, S.; Gorus, M.S. Are BRICS countries pollution havens? Evidence from a bootstrap ARDL bounds testing approach with a Fourier function. Sustain. Cities Soc. 2020, 55, 102035. [CrossRef]

39. Balsalobre-Lorente, D.; Gokmenoglu, K.K.; Taspinar, N.; Cantos-Cantos, J.M. An approach to the pollution haven and pollution halo hypotheses in MINT countries. Environ. Sci. Pollut. Res. 2019, 26, 23010-23026. [CrossRef]

40. Rana, R.; Sharma, M. Dynamic causality testing for EKC hypothesis, pollution haven hypothesis and international trade in India. J. Int. Trade Econ. Dev. 2019, 28, 348-364. [CrossRef]

41. Khan, A.; Chenggang, Y.; Hussain, J.; Bano, S. Does energy consumption, financial development, and investment contribute to ecological footprints in BRI regions? Environ. Sci. Pollut. Res. 2019, 26, 36952-36966. [CrossRef]

42. Ali, S.; Dogan, E.; Chen, F.; Khan, Z. International trade and environmental performance in top ten-emitters countries: The role of eco-innovation and renewable energy consumption. Sustain. Dev. 2021, 29, 378-387. [CrossRef]

43. Nathaniel, S.P.; Murshed, M.; Bassim, M. The nexus between economic growth, energy use, international trade and ecological footprints: The role of environmental regulations in N11 countries. Energy Ecol. Environ. 2021, 6, 496-512. [CrossRef]

44. Usman, M.; Jahanger, A. Heterogeneous effects of remittances and institutional quality in reducing environmental deficit in the presence of EKC hypothesis: A global study with the application of panel quantile regression. Environ. Sci. Pollut. Res. 2021.

45. Rehman, A.; Radulescu, M.; Ma, H.; Dagar, V.; Hussain, I.; Khan, M.K. The Impact of Globalization, Energy Use, and Trade on Ecological Footprint in Pakistan: Does Environmental Sustainability Exist? Energies 2021, 14, 5234. [CrossRef]

46. Lasisi, T.T.; Alola, A.A.; Eluwole, K.K.; Ozturen, A.; Alola, U.V. The environmental sustainability effects of income, labour force, and tourism development in OECD countries. Environ. Sci. Pollut. Res. 2020, 27, 21231-21242. [CrossRef]

47. Qi, Y.; Xu, Z. Research on China's Regional Economic Linkages: Based on the Analyses of Carbon Emission Transfers and Labor Mobility. Chin. J. Urban. Environ. Stud. 2019, 7, 1950002. [CrossRef] 
48. Anwar, A.; Younis, M.; Ullah, I. Impact of urbanization and economic growth on $\mathrm{CO}_{2}$ emission: A case of for east Asian countries. Int. J. Environ. Res. Public Health 2020, 17, 2531. [CrossRef]

49. Abbasi, K.R.; Shahbaz, M.; Jiao, Z.; Tufail, M. How energy consumption, industrial growth, urbanization, and $\mathrm{CO}_{2}$ emissions affect economic growth in Pakistan? A novel dynamic ARDL simulations approach. Energy 2021, 221, 119793. [CrossRef]

50. Rahman, Z.U.; Ahmad, M. Modeling the relationship between gross capital formation and CO2 (a) symmetrically in the case of Pakistan: An empirical analysis through NARDL approach. Environ. Sci. Pollut. Res. 2019, 26, 8111-8124. [CrossRef]

51. Bekhet, H.A.; Yasmin, T.; Al-Smadi, R.W. Dynamic linkages among financial development, economic growth, energy consumption, $\mathrm{CO}_{2}$ emissions and gross fixed capital formation patterns in Malaysia. Int. J. Bus. Glob. 2017, 18, 493-523. [CrossRef]

52. Hakimi, A.; Hamdi, H. Environmental effects of trade openness: What role do institutions have? J. Environ. Econ. Policy 2020, 9 , 36-56. [CrossRef]

53. Usman, M.; Yaseen, M.R.; Kousar, R.; Makhdum, M.S.A. Modeling financial development, tourism, energy consumption, and environmental quality: Is there any discrepancy between developing and developed countries. Environ. Sci. Pollut. Res. 2021. [CrossRef]

54. Manning, W.G. The logged dependent variable, heteroscedasticity, and the retransformation problem. J. Health Econ. 1998, 17, 283-295. [CrossRef]

55. World Bank. World Bank Database. 2020. Available online: https://databank.worldbank.org/data/source/world-developmentindicators (accessed on 20 August 2021).

56. Gygli, S.; Haelg, F.; Potrafke, N.; Sturm, J.E. The KOF globalisation index-revisited. Rev. Int. Organ. 2019, 14, 543-574. [CrossRef]

57. Dreher, A. Does globalization affect growth? Evidence from a new index of globalization. Appl. Econ. 2006, 38, 1091-1110. [CrossRef]

58. IMF (International Monetary Fund). International Monetary Fund Database. 2020. Available online: https://data.imf.org/ (accessed on 20 March 2021).

59. Levin, A.; Lin, C.F.; Chu, C.S.J. Unit root tests in panel data: Asymptotic and finite-sample properties. J. Econom. 2002, 108, 1-24. [CrossRef]

60. Im, K.S.; Pesaran, M.H.; Shin, Y. Testing for unit roots in heterogeneous panels. J. Econom. 2003, 115, 53-74. [CrossRef]

61. Maddala, G.S.; Wu, S. A comparative study of unit root tests with panel data and a new simple test. Oxford Bull. Econ Stat. 1999, 61, 631-652. [CrossRef]

62. Phillips, P.C.; Perron, P. Testing for a unit root in time series regression. Biometrika 1988, 75, 335-346. [CrossRef]

63. Hossain, M.S. Panel estimation for CO2 emissions, energy consumption, economic growth, trade openness and urbanization of newly industrialized countries. Energy Policy 2011, 39, 6991-6999. [CrossRef]

64. Kao, C. Spurious regression and residual-based tests for cointegration in panel data. J. Econom. 1999, 90, 1-44. [CrossRef]

65. Johansen, S. A Statistical Analysis of Cointegration for I Variables; Cambridge University Press: Cambridge, UK, 1995; Volume 11, pp. 25-59.

66. Khalid, K.; Usman, M.; Mehdi, M.A. The determinants of environmental quality in the SAARC region: A spatial heterogeneous panel data approach. Environ. Sci. Pollut. Res. 2021, 28, 6422-6436. [CrossRef] [PubMed]

67. Usman, M.; Makhdum, M.S.A. What abates ecological footprint in BRICS-T region? Exploring the influence of renewable energy, non-renewable energy, agriculture and financial development. Renew. Energy 2021, 179, 12-28. [CrossRef]

68. Intisar, R.A.; Yaseen, M.R.; Kousar, R.; Usman, M.; Makhdum, M.S.A. Impact of Trade Openness and Human Capital on Economic Growth: A Comparative Investigation of Asian Countries. Sustainability 2020, 12, 2930. [CrossRef]

69. Pedroni, P. Purchasing power parity tests in cointegrated panels. Rev. Econ. Stat. 2001, 83, 727-731. [CrossRef]

70. McCoskey, S.; Kao, C.A. Monte Carlo Comparison of Tests for Cointegration in Panel Data. 1999. Available online: https: / / papers.ssrn.com/sol3/papers.cfm?abstract_id=1807953 (accessed on 13 March 2021).

71. Mark, N.C.; Sul, D. Nominal exchange rates and monetary fundamentals: Evidence from a small post-Bretton Woods panel. J. Int. Econ. 2001, 53, 29-52. [CrossRef]

72. Pesaran, M.H.; Shin, Y.; Smith, R.P. Pooled mean group estimation of dynamic heterogeneous panels. J. Am. Stat. Assoc. 1999, 94, 621-634. [CrossRef]

73. Pesaran, M.H.; Smith, R. Estimating long-run relationships from dynamic heterogeneous panels. J. Econometrics 1995, 68, 79-113. [CrossRef]

74. Hansen, B.E. Threshold effects in non-dynamic panels: Estimation, testing, and inference. J. Econometrics 1999, 93, 345-368. [CrossRef]

75. Hansen, B.E. Sample splitting and threshold estimation. Econometrica 2000, 68, 575-603. [CrossRef]

76. Yuelan, P.; Akbar, M.W.; Hafeez, M.; Ahmad, M.; Zia, Z.; Ullah, S. The nexus of fiscal policy instruments and environmental degradation in China. Environ. Sci. Pollut. Res. 2019, 26, 28919-28932. [CrossRef]

77. Ahmed, Z.; Asghar, M.M.; Malik, M.N.; Nawaz, K. Moving towards a sustainable environment: The dynamic linkage between natural resources, human capital, urbanization, economic growth, and ecological footprint in China. Resour. Policy 2020, 67, 101677. [CrossRef]

78. Yang, B.; Jahanger, A.; Usman, M.; Khan, M.A. The dynamic linkage between globalization, financial development, energy utilization, and environmental sustainability in GCC countries. Environ. Sci. Pollut. Res. 2021, 28, 16568-16588. [CrossRef] 
79. Pata, U.K. Linking renewable energy, globalization, agriculture, $\mathrm{CO}_{2}$ emissions and ecological footprint in BRIC countries: A sustainability perspective. Renew. Energy 2021, 173, 197-208. [CrossRef]

80. Jahanger, A.; Usman, M.; Ahmed, P. A step towards sustainable path: The effect of globalization on China's carbon productivity from panel threshold approach. Environ. Sci. Pollut. Res. 2021. [CrossRef]

81. Jahanger, A.; Usman, M.; Balsalobre-Lorente, D. Autocracy, democracy, globalization, and environmental pollution in developing world: Fresh evidence from STIRPAT model. J. Public Aff. 2021, e2753. [CrossRef]

82. Usman, M.; Khalid, K.; Mehdi, M.A. What determines environmental deficit in Asia? Embossing the role of renewable and non-renewable energy utilization. Renew. Energy 2021, 168, 1165-1176. [CrossRef]

83. Usman, M.; Kousar, R.; Makhdum, M.S.A. The role of financial development, tourism, and energy utilization in environmental deficit: Evidence from 20 highest emitting economies. Environ. Sci. Pollut. Res. 2020, 27, 42980-42995. [CrossRef]

84. Jiang, C.; Ma, X. The impact of financial development on carbon emissions: A global perspective. Sustainability 2019, 11, 5241. [CrossRef]

85. Farhani, S.; Chaibi, A.; Rault, C. $\mathrm{CO}_{2}$ emissions, output, energy consumption, and trade in Tunisia. Econ. Model. 2014, 38, 426-434. [CrossRef]

86. Yang, B.; Usman, M.; Jahanger, A. Do industrialization, economic growth and globalization processes influence the ecological footprint and healthcare expenditures? Fresh insights based on the STIRPAT model for countries with the highest healthcare expenditures. Sustain. Prod. Consump. 2021, 28, 893-910. [CrossRef]

87. Wang, Y.; Zhou, T.; Chen, H.; Rong, Z. Environmental homogenization or heterogenization? The effects of globalization on carbon dioxide emissions, 1970-2014. Sustainability 2019, 11, 2752. [CrossRef]

88. Etokakpan, M.U.; Solarin, S.A.; Yorucu, V.; Bekun, F.V.; Sarkodie, S.A. Modeling natural gas consumption, capital formation, globalization, $\mathrm{CO}_{2}$ emissions and economic growth nexus in Malaysia: Fresh evidence from combined cointegration and causality analysis. Energy Strategy Rev. 2020, 31, 100526. [CrossRef]

89. Ling, C.H.; Ahmed, K.; Muhamad, R.B.; Shahbaz, M. Decomposing the trade-environment nexus for Malaysia: What do the technique, scale, composition, and comparative advantage effect indicate? Environ. Sci. Pollut. Res. 2015, 22, 20131-20142. [CrossRef] 